\title{
Öykü Anlatıcılığı ve Futbol: ‘Dört Büyüikler'in İnternet Sitelerinde Aktarılan Öyküler Üzerine Bir İnceleme ${ }^{1}$
}

\author{
DOI: 10.26466/opus.592530
}

*

\section{Özge Uğurlu Akbaș* - Sadık Çalışkan**}

* Dr. Öğretim Üyesi, Üsküdar Üniversitesi, İletişim Fakültesi, Üsküdar/Türkiye

E-Posta: ozge.ugurlu@uskudar.edu.tr

ORCID: 0000-0002-2220-1757

** Öğretim Görevlisi, İnönü Üniversitesi, Yabancı Diller Yüksek Okulu, Malatya/ Türkiye

E-Posta: $\underline{\text { sadikc@yahoo.com }}$

ORCID: 0000-0001-6899-0424

\section{Öz}

Psikoloji ve sinirbilim alanında yapılan çalışmalar öykülerin tüketicilerin marka algısını ve markaya olan bağhllı̆̆ını etkilediğini göstermektedir. Markalar tüketicilerin zihninde belli bir kurum, ürün ya da hizmet ile ilgili beklentilerin, hatıraların, öykülerin bir toplamı olarak kabul edilmektedir. Bu anlamda öyküler, markalar ve tüketiciler arasında duygusal bir bağ kurmanın en önemli araçlarından biri olarak görülür. Spor kulüpleri de marka değeri yaratan stratejiler kurgularken, taraftarlar ile iletişim süreçlerinde öykü ve öykü anlatıcılığı unsurlarından yararlanmaktadır. Bu çalışmada Türkiye'nin dört büyük spor kulübü olarak kabul edilen Beşiktaş JK, Fenerbahçe SK, Galatasaray SK ve Trabzonspor'un resmi web sayfalar analiz edilmiş, incelemede Fog ve arkadaşlarının çekirdek öykü modeli kullanılmıştır. Buna göre öykünün temelini oluşturan dört temel unsur bulunmaktadır. Bu dört unsur "mesaj, çatışma, karakterler ve olay örgüsü" olarak tanımlanmaktadır. Çalışmada bahsi geçen takımların web sayfalarında taraftarları ile iletişim kurarken hangi tür öykülere yer verdiği ve öykü anlatıcılığı unsurlarını ne ölçüde kullandı̆̆ı gibi soruların yanıtları aranmıştır.

Anahtar Kelimeler: Spor İletişimi, Öykü Anlatıcılı̆̆ı, Öykü, Dört Büyükler.

\footnotetext{
${ }^{1}$ Makale 2018 yılı "International Symposium on Multidisciplinary Academic Studies (IMASES), "Spor iletişiminde Hikaye Anlatıcılığı Kullanımı: Dört Büyükler Örneği" başıklı bildiriden üretilmiştir.
} 


\title{
Storytelling and Football: An Investigation On The Stories of " Four Great Team's Web Sites ${ }^{2}$
}

\begin{abstract}
Studies in the field of psychology and neuroscience show that the stories affect consumers' perception of the brand and its commitment to the brand. Brands are considered as a sum of the anticipations, memories, and stories about a certain company, product or service in the minds of consumers. In this sense, stories are considered as one of the most important means of establishing an emotional connection between brands and consumers. Sports clubs also use story and storytelling elements when communicating with their supporters. In this study, Turkey's four major sports clubs, Beşiktaş JK, Fenerbahçe SK, Galatasaray SK and Trabzonspor's official web pages were viewed by using the core story model of Fog et al. Accordingly, there are four basic elements that form the basis of the story. These four elements are defined as "messages, conflicts, characters and event patterns". The questions we tried to answer are; how storytelling is used in these pages, what kinds of stories are used and how storytelling is used while communicating with supporters.
\end{abstract}

Keywords: Sports Communication, Storytelling, Story, Four Great Teams

\footnotetext{
2 The article derived from the paper titled "The Use of Storytelling in Sports Communication: Example of Four Great Teams" at "International Symposium on Multidisciplinary Academic Studies (IMASES), in 2018
} 


\section{Giriş}

Öykü anlatıcılığı markaların bir kimlik kazanması için en etkili araçlardan biridir. Bir ürün ya da hizmetin ete kemiğe bürünmesi ve tüketicilerin duygularına hitap etmesi öyküler ile gerçekleşir. Marka ve hedef kitlesi arasında güçlü bir ilişkinin tesisi için bu öykülerin marka kişiliğini yansıtması, özgün olması beklenir. Holt bu konuda "her marka, bir öyküyü bünyesinde taşır ve tüketiciler markanın öyküsünü deneyimlemek için ürünlerini satın alırlar. Marka aslında öykü ile sarılmış bir üründür" der (Holt, 2004). Holt'a göre markalar bütünüyle öykülerden ibarettir. Baker ve Boyle ise, öykü anlatıcllğını insanı insan yapan en önemli etkinliklerden biri olarak görür, bir insan aslında kendisinin anlattı̆̆ ve başkaları tarafından kendisi hakkında anlatılan öykülerin toplamıdır. Herkes doğası gereği bir öykü anlatıcısıdır ve dünyada güzel bir öykü dinlemek ya da bir öyküyü başkalarına anlatmak kadar insanların sevdiği pek az etkinlik vardır (2009, s.80). Lusensky'e göre ise markaların rolü değişmiştir. Markaların görevi artık bir ürünü diğerinden farkl1laştırmak değil, insanlara bir anlam kazandırmak ve kim olduklarını anlatmada yardımci olmaktır.

Spor eski çağlardan beri kültürün bir parçası olmuştur. Geçmişte eğlence, savaş hazırlığı ya da dini ayinlerin bir parçası olarak yapılan spor artık günlük hayata nüfuz etmektedir. Dünyada 4 milyardan fazla insan günlük hayatında bir şekilde spor ile ya sporcu, izleyici ya da taraftar olarak ilişki halindedir. Spor dallarından özellikle futbol hem şehir, semt, ilçe ya da şehir gibi küçük gruplar hem de ülke ya da küresel olarak insanların sohbetlerinde, tükettikleri medyalarda, yansıttıkları kimliklerde, anlattıkları öykülerde birleştirici bir güç olarak görülmektedir. Takımları, oyuncuları ve taraftarları ile spor endüstrisinin 600 - 700 milyar dolara ulaşması bu duygusal bağla ilişkilidir. Futbol büyük bir endüstri olarak dönüşmekte ve bu duygusal bağın kurulmasında kulüplerin kendileriyle özdeşleştirdikleri değerleri belli öykülerle aktarması ve taraftarların bu öykülerin birer parçası haline gelmesi oldukça önemli görülmektedir. Türkiye'de de futbol kulüpleri günlük hayatın önemli bir parçasını oluşturmakta aynı zamanda toplumun bir arada olmasında da yadsınamaz bir rol üstlenmektedir. Farklı ailelerden, farklı alt kültürlerden, etnisiteden gelen insanlar aynı spor kulübünün renkleri ve bayrağı etrafında birleşebilmektedir. 
Türk futbol tarihine bakıldığında geçmişlerinde lig şampiyonluğu olan Beşiktaş JK, Fenerbahçe SK, Galatasaray SK ve Trabzonspor kulüpleri ‘Dört Büyükler' olarak adlandırılmaktadır. KPMG Avrupa Eliti 2018 - Futbol Kulüpleri Değerlendirme Raporu'na göre Beşiktaş, Fenerbahçe ve Galatasaray Avrupa' da da en değerli 100 futbol takımı arasında görülmektedir. Görülen o ki, futbol kulüpleri birer marka olarak kabul edildiğinde bir yandan mevcut taraftarların korumak diğer yandan yeni taraftarlar kazanmak için bir takım hamlelerde bulunmaktadır. Bu açıdan da futbol kulüpleri farklı sosyo ekonomik yapıdan, farklı kültürlerden, dinlerden, siyasi görüşten insanı bir araya getiren ortak bir bağa sahiptir. Bu anlamda taraftarlar oldukça heterojen bir grup olarak değerlendirilmekte ve onları bir arada tutacak bu bağ bir bakıma futbol kulübü markası ve onun temsil ettiği değerler etrafında şekillenmektedir.

Çalışmada Türkiye'nin dört büyük spor kulübü olarak kabul edilen Beşiktaş JK, Fenerbahçe SK, Galatasaray SK ve Trabzonspor'un resmi web sayfaları incelemiş olup, incelemede Fog ve arkadaşlarının çekirdek öykü modeli üzerinden değerlendirmeler yapılmaktadır. Buna göre öykünün temelini oluşturan dört temel unsur bulunmaktadır. Bu dört unsur "mesaj, çatışma, karakterler ve olay örgüsü" olarak tanımlanmaktadır. Çalışmada bahsi geçen takımların resmi sayfaları üzerinden taraftarları ile iletişim kurarken hangi tür öykülere yer verdiği ve bu öykülerin 'öykü anlatıcllı̆̆ unsurlarını' ne ölçüde içerdiği sorularının yanıtları aranmıştır. Araştırma 0110 Nisan 2019 tarih aralığı içerisinde gerçekleştirilmiştir. Çalışmanın ilk bölümünde öykü kavramı tanımlanmış, öyküyü oluşturan unsurlar üzerinden değerlendirmeler yapılmıştır. İkinci bölümde öykü anlatıcılığı tarihsel bağlamda incelenmiş ve önemi üzerinde durulmuştur. Son bölümde ise futbol ve öykü anlatıcılığı ilişkisi tanımlanmakta ve ‘Dört Büyükler'in web sitelerinde yer alan öyküler incelenmektedir.

\section{Öykü Kavramına Genel Bakış}

Öykünün edebiyattan gazeteciliğe farklı disiplinlerde sayısız tanımı bulunur. Herskovitz ve Crystal (2010, s.21) öyküyü bir ihtiyaç olarak tanımlar. Öykü insanların ve uzun süreli duygusal bir bağ kurabileceği bir karaktere duyulan ihtiyaçtır. Sinclair ise öyküyü daha geniş bir çerçevede tanımlar; yazarlara 
göre öykü yapılandırılması bir olay örgüsüne bağlı olan, kurgu ya da gerçeğin sözlü ya da yazılı betimlemesi olarak değerlendirilir (2005, s.54).

Fransız felsefeci Roland Barthes'ın öykü tanımı şöyledir; “Her şey öyküdür ya da öykü olarak kabül edilebilir. Sözlü ya da yazılı destanlar, masallar, kısa öyküler, tablolar, vitray pencereler, filmler, yerel haberler, tarih ve benzeri herşey öykünün farklı türleridir. Tarihin herhangi bir zamanında öykünün olmadığı bir an gösterilemez. Tüm sınıfların, grupların ortak noktası öyküye sahip olmaları ve öyküden zevk almalarıdır" (1975, s.237). Bu genelleyici tanımın aksine kimi düşünürler ise öyküyü tanımlarken belli özelliklere vurgu yapar. Örneğin, Barbara Czarniawska öyküyü zaman dizinsel olarak birbirine bağlı olayları ve eylemleri anlatan, belirli bir olay örgüsü olan sözlü ya da yazılı metinler olarak tanımlar (2004, s.17). Stephen Denning (2016) ise öykü için iki tanım kullanır. Geniş anlamı ile öykü, anlatılan ve nakledilen her şeydir. Daha dar anlamıyla, gerçek ya da kurgu olan nedensellik bağı bulunan olayların anlatımı ya da naklidir. Bu noktada "öykünün nedenselliğe dayalı olması ve insan eylemlerinin ya da olayların insanları etkilemesi ile birbirine bağlanması" görüşünün vurgulandığı görülmektedir.

Bilgelik öykülerle aktarılır. Her kültürden ve zamandan büyük ruhani üstatlar öğretilerini gerçekleştirmek için öykülere bel bağlar. Anlattıkları kıssa ve öyküler ile takipçilerini mutlak gerçeğe ulaştırmaya çalışırlar. Antony de Mello bir üstadın öyküsünü anlatır. Üstadın anlattığ1 kıssalardan ve öykülerden bıkan öğrencileri daha derin ve gerçek bilgiye ulaşmak istediklerini söyleyip itiraz ettiklerinde üstat şöyle karşlık verir; "Anlamak zorundasınız canlarım gerçek ve bir insan arasındaki en kısa mesafe öyküdür" (Bausch, 2004 s.52).

Simmons öykülerle ilgili görüşünü "insan olmak öyküye sahip olmak demektir" şeklinde ifade etmektedir. Televizyonun, sinemanın, kitapların, yazının ve hatta ateşin bile olmadığı bir dönemden bugüne insanlığın DNA'sına işleyen onu büyüten, geliştiren, hayatta kalmasını sağlayan öykü anlatıcılığıdır. Aynı zamanda kültürleri şekillendiren, zor öğrenilen bilgileri bir nesilden diğerine aktarımını sağlayan da öykü anlatıcılığıdır. Öyküler eğlendirir, aydınlatır ahlaki değerlerin anlaşılmasına ve aktarılmasına yardımcı olur (2006, s.1).

Haven, 'Story Proof adlı eserinde öykünün tanımını şöyle verir: “Öykü bir karakterin engelleri aşma ve önemli bir amaca ulaşma mücadelesinin karak- 
tere dayalı detaylı anlatımıdır". Buna bağlı olarak Haven etkili öykü yapısının özelliklerini şu şekilde sıralamaktadır (2014, s.29): Öyküler üstün hafıza ve ileri kavrayış sağlar, bağlam ve ilişki oluşturur, empati yaratır, üst düzey bağlllık sağlar. Bunların yanında öykü, okuyucuları ve dinleyicileri dikkatini vermeye daha iyi teşvik eder ve anlam yaratmayı geliştirir.

Fog ve arkadaşlarına göre; doğanın dört temel elementi olan toprak, rüzgâr, ateş ve su gibi öykünün ana temelini oluşturan dört temel unsur bulunur. Aristo' dan Hans Christian Andersen'in öykülerine kadar yapılan tüm analizler bu temel unsurları ortaya çıkartmıştır. Markaların öykü anlatıcılığı uygulamalarını peri masalı modeline göre analiz eden Fog ve arkadaşları (2010, s.32) bu dört unsuru 'mesaj, çatışma, karakterler ve olay örgüsü' olarak belirler. 'Mesaj' öykünün özü ya da verdiği derstir. Düzeni yeniden tesis etmek için arayışın yanında 'çatışma' ise öykünün itici gücünü oluşturmaktadır. Başka bir ifadeyle herhangi bir çatışma yoksa öykü de yok demektir. Bunun insan doğası ile ilgili olduğu belirtilmektedir. Dayanak noktasını insanların daima belli bir uyum ve denge araması ve her hangi bir problem ile karşılaşıldığında düzen ve dengeyi yeniden tesis etmek için harekete geçmesi oluşturmaktadır. Öykü içerisinde eylem mevcut uyumu bozan bir değişiklikle ya da böyle bir olayın gerçekleşme endişesi veya korkusu ile başlamaktadır. Düzenin tekrar kurulabilmesi içinse kahramanın mücadele etmesi gerekmektedir. Çatışmanın daima iyi ve kötü arasında olduğu vurgulanmaktadır. Çatışma sırasında çatışılan varlık başka bir kişi, başka bir marka, doğa, toplum, teknoloji ya da kişinin bizzat kendisi de olabilir. Bu noktada önemle altı çizilmesi gereken husus şudur; öykü anlatıc1lığında çatışma her zaman olumsuz olarak kabul edilmemekte aksine çatışma yolu ile öykü anlatıcısı doğru ve yanlış ile ilgili algısını hedef kitleye iletmektedir (Fog ve ark., 2010, s.35).

Öykü anlatıcılığının bir diğer unsuru 'karakterlerdir'. Öykünün dönüm noktası çatışma olarak görülmesine karşın çatışmanın ortaya çıkması karşılıklı olarak birbirini etkileyen güçlü karakterlere bağlıdır. Genel anlamda başarılı bir çatışma için karşıt gündemlere sahip bir kahramana ve kötü karaktere gerek duyulmaktadır. Bu aşamada düşman hem fiziksel hem de psikolojik olarak farklı kisvelerle ortaya çıkabilir. Örneğin tırmanılması gereken bir dağ gibi görünen statik bir engel daha derinde dağa tırmanma korkusu olan gerçek düşmanı gösterebilir (Fog ve ark., 2010, s.41). Fog ve arka- 
daşlarının ortaya atmış oldukları karakterler, Jung'un arketipleri temel alınarak oluşturulmuştur. Bu arketipler 12 tanedir. Karakter arketipleri özelliklerine göre şu şekilde sınıflandırılmıştır:

Tablo 1. Klasik Karakter Şeması (Fog ve ark., 2010, s. 94'den alınarak Türkçeleştirilmiştir)

\begin{tabular}{|c|c|c|c|}
\hline $\begin{array}{l}\text { Karakter } \\
\text { Figürü }\end{array}$ & Özellikleri & Amaci & Düşmanı \\
\hline Yaratıcı & Hayal gücü ve yaratıcılık & $\begin{array}{l}\text { Kendini ifade etmenin yeni } \\
\text { yollarını yaratmak ve } \\
\text { geliştirmek }\end{array}$ & $\begin{array}{l}\text { Tekrara düşme ve } \\
\text { edilgenlik }\end{array}$ \\
\hline Hükümdar & $\begin{array}{l}\text { Yönetebilme yeteneği, } \\
\text { hâkimiyet ve mükemmellik }\end{array}$ & $\begin{array}{l}\text { Kontrolü, güvenliği ve } \\
\text { düzeni elinde tutmak }\end{array}$ & $\begin{array}{l}\text { İsyan ve } \\
\text { düzensizlik }\end{array}$ \\
\hline $\begin{array}{l}\text { Siradan } \\
\text { Adam }\end{array}$ & Sıradan ve açık sözlü & $\begin{array}{l}\text { Toplumun bir parçası } \\
\text { olarak huzuru bulmak }\end{array}$ & $\begin{array}{l}\text { Çevrede } \\
\text { kabul görmeme }\end{array}$ \\
\hline Bilge & Bilgelik ve uzmanlık & $\begin{array}{l}\text { Gerçeğin peşinde koşmak } \\
\text { ve hayatın büyük } \\
\text { gizemlerini keşfetmek }\end{array}$ & $\begin{array}{l}\text { Cehalet ve } \\
\text { yalanlar }\end{array}$ \\
\hline Bakıcı & Şefkatli ve fedakâr & $\begin{array}{l}\text { Başka insanları destekle- } \\
\text { mek ve yardım etmek }\end{array}$ & Bencillik \\
\hline Kâşif & Meraklı ve gözü pek & $\begin{array}{l}\text { Dünyayı keşfetmek, yeni } \\
\text { diyarlara seyahat etmek }\end{array}$ & $\begin{array}{l}\text { Geri kafalılık } \\
\text { ve günlük } \\
\text { hayatın zorlukları } \\
\end{array}$ \\
\hline Masum & $\begin{array}{l}\text { Dürüstlük, masumiyet } \\
\text { ve yüce gönüllü }\end{array}$ & $\begin{array}{l}\text { Doğruluğu ve adaleti } \\
\text { savunmak }\end{array}$ & Yanlış yapmak \\
\hline Asi & Asi ve inatçı & $\begin{array}{l}\text { Alışlmışın tersini yapmak } \\
\text { ve kuralları çiğnemek }\end{array}$ & $\begin{array}{l}\text { Sistem ve baskın } \\
\text { normlar }\end{array}$ \\
\hline Kahraman & $\begin{array}{l}\text { Cesur ve sağlam bir } \\
\text { şekilde kendine güvenen }\end{array}$ & $\begin{array}{l}\text { Daha iyi bir dünya için } \\
\text { savaşmak }\end{array}$ & $\begin{array}{l}\text { Korku, zayıflık } \\
\text { ve kötülük }\end{array}$ \\
\hline Aşık & Sicakkanlı ve duygusal & $\begin{array}{l}\text { Kalbini dinlemek, duygu- } \\
\text { sal ihtiyaçlarını karşılamak }\end{array}$ & $\begin{array}{l}\text { Mantık ve } \\
\text { tutku eksikliği }\end{array}$ \\
\hline Sihirbaz & Fikir dolu ve şaşırtıcı & $\begin{array}{l}\text { Hayalleri gerçekleştirmek } \\
\text { ve hiçbir şeyin imkânsız ol- } \\
\text { madığını göstermek }\end{array}$ & $\begin{array}{l}\text { Durgunluk ya da } \\
\text { kontrol eksikliği }\end{array}$ \\
\hline Soytarı & Komik ve Neşeli & $\begin{array}{l}\text { Başkalarını eğlendirmek ve } \\
\text { hayatın tadını çıkarmak }\end{array}$ & Can sikıntıs1 \\
\hline
\end{tabular}

Fog ve arkadaşlarına göre mesaj, çatışma ve karakterler yerini aldıktan sonra olması gereken öykünün nasıl ilerleyeceğine karar vermektir. Öykünün akışı ve olaylar, seslenilen kitlenin deneyimi için elzemdir. Öykü belli bir zaman döngüsünde olayların ilerleyişi olarak kabul edildiği için, olayların sıralaması da önemlidir. Öykünün doğru bir şekilde ilerleyebilmesi ve 
seslenilen kitlenin öyküye ilgisinin devamı olayların sıralanışına bağlı kalarak kurgulanmalıdır.

Genel anlamda öyküler giriş, gelişme ve sonuç olmak üzere üç bölümde ele alınabilir. Girişte mizansen kurulmakta, gelişme bölümünde bir değişiklik çatışmaya sebep olmakta ve öykünün geri kalanındaki değişkenler ortaya çıkmaktadır. Öyküler süresince çatışma artabilmekte ancak nihayetinde çözüme kavuşmakta ve öykü sona ermektedir. Fog ve arkadaşlarına göre en küçük öykülerde bile bu akışın görüldüğü kabul edilmektedir.

\section{Öykü Anlatıcılığı ve Önemi}

Ulusal Öykü Anlatıcılığı Derneği (1997) öykü anlatıcıllğını tanımlarken, öykü ve anlatıcılık olarak iki ayrı başlık üzerinden değerlendirmektedir. Buna göre öykü belli tarzda belli bir anlatı yapısı, bir dizi karakteri ve bir bütünlüğü olan bir kavram olarak nitelendirilmektedir. Bu tanımın devamında öykünün işlevleri şu şekilde sunulmaktadır: "Biz, öyküleri birikmiş bilgeliği, inançları ve değerleri aktarmak için kullanırız. Öykülerle olayların nasıl olduğunu, niçin olduğunu, rollerimizi ve amaçlarımızı açıklarız. Öyküler bilginin yapıtaşları, hafıza ve öğrenmenin temelleridir. Öyküler bizim insan yanımızla bağımızdır, hareketlerimizin muhtemel sonuçlarını öngörmeyi öğreterek geçmişi, şu anı ve geleceği birbirine bağlar".

Eldrbarry (2016) ise 'anlatıcılık' kavramını sadece sözlü öykülerle sınırlandırmaktadır. Yazara göre anlatııllık canlı olarak gerçekleşen, kişiden kişiye sözlü olarak aktarılan, bir öykünün dinleyiciye fiziksel sunumu olarak tanımlanmaktadır. Bunun yanında anlatıcılığın, anlatıcı ve dinleyici arasında doğrudan bir teması içermesinin gerekliliği de önem kazanmaktadır. Bu noktada anlatıcının rolü; gerekli dili, seslendirmeyi ve fizikselliği etkin bir şekilde hazırlayıp sunmak ve öykünün görüntülerini verimli bir şekilde iletmek olarak ifade edilmektedir. Dinleyicinin rolü ise aktif olarak canl1çoklu duyumsal görüntüleri, hareketleri, karakterleri ve olayları zihinde yaratmaktır. Dinleyici bunu geçmişteki deneyimlerine, inançlarına ve kavrayışlarına göre yapmakta, dinleyicinin zihninde oluşan öykü eşsiz olarak görülmekte ve her bir birey için kişisel olarak düşünülmektedir.

Dünyada yaşamış pek çok medeniyetin, düşünürün ve bilim insanının ortak noktalarından bir tanesi öykü ve öykü anlatıcllı̆ının önemini fark etmiş olmalarıdır. Bir Kızılderili atasözü şöyle der: “Öykü anlatanlar dünyayı 
yönetenlerdir". Platon da benzer şekilde toplumu yönetenlerin öykü anlatıcılar olduğunu söylemektedir (Strangelove, 2010, s.181).

Amerikalı şair Muriel Rukeyser 'The Speed of Darkness' şiirinde “Evreni oluşturan atomlar değil öykülerdir" der (Kaufman ve Herzog, 2006, s.135). 'Kahramanin Sonsuz Yolculuğu' eserinde Joseph Campbell, Bill Moyers ile yaptığı söyleşide Goethe'ye atıfta bulunarak "Eğer dünyayı değiştirmek isterseniz, metaforu değiştirmeniz gerekir" derken, insanın metaforlardan oluştuğunun altını çizmektedir (Campbell ve Moyers, 2011, s.183). İnsanların kendi hayatları ya da başkalarının hayatlarına ilişkin anlattıkları öyküler her yere nüfuz eden bir metin formu olarak tanımlanmaktadır. Bu formla deneyimler kurulmakta, yorumlanmakta ve paylaşılmaktadır. Gece rüyaları, kâbuslar, gündüz düşleri, hatırlama, tahmin etme, umut etme, umutsuzluk, inanma, şüphe duyma, planlama, eleştirme, dedikodu yapma, öğrenme, nefret etme ve aşık olma hep öykülerle oluşmaktadır (Shankar ve ark, 2010, s.431). Tüm bunların aktarılma ve paylaşılma sürecinde ise insanoğlu daima öykülerden etkilenir. Öykü anlatmak ya da dinlemek insanların kurdukları en eski ve en eğlenceli iletişim şekillerinden biri olarak kabul görmektedir.

Taş devri döneminden 21. yüzyıla, insanlığın gelişimini inceleyen Harari'ye göre de Homo Sapiens'i, Neanderthal gibi önceki türlerden ayıran ve yok olmadan dünyayı yönetmesini sağlayan şey öykülerdir. Tüm diğer canlılar iletişim sistemlerini gerçekliği tanımlamak için kullanırken Homo Sapiens iletişim sistemini yeni gerçeklikler yaratmak için kullanmaktadır. Bu bakış açısıyla Harari'ye göre Homo Sapiens Tanrılar, uluslar, para ve insan hakları gibi kavramları üretebilme ve bunlara inanma gibi eşsiz bir yeteneğe sahiptir. Bunun yanı sıra din, politik yapılar, ticaret ağları ve yasal kurumlar gibi tüm geniş çaplı insani iş birliği sistemlerinin temelinin de öykülere dayalı olduğunu savunmaktadır (2012, s.48-50). Gottschall, 'The Storytelling Animal: How Stories Make Us Human' (Öykü Anlatan Hayvan: Öyküler Bizi Nasıl İnsan Yapar) adlı eserinde daha da öteye giderek, insanı "homo narratus" yani öykü anlatan hayvan olarak tanımlamaktadır. Yazara göre insan, hayatı öykülerle yaşamaktadır. Öykülerin insan hayatındaki rolü geleneksel romanların ve filmlerin çok ötesindedir. İnsanın hayatını yönetenin öyküler olduğu söylenmektedir. Öyküler insanların motive olma, ilham alma ve ikna olma yolu olarak da kabul edilmektedir (2012, s.11). 'Human' (İnsan) adlı eserinde nörobilimci Micheal Gazzaniga, genel 
olarak sanatın ve özel olarak öykü anlatıcılığının insanın biyolojik evrimindeki rolüne vurgu yapar. Gazzaniga, öykü anlatıcllı̆ının insana hayatta kalma avantajı sağlayarak, gerekli bilgi ve yetenekleri değiş tokuş etmede kolaylık sağladığını belirtmektedir. Bu bakış açısıyla öyküler düşmanlardan ve avcılardan nasıl saklanılması gerektiğini, yiyecek, barınak, su ve benzeri ihtiyaçların nasıl elde edileceği bilgisinin aktarılmasını sağlamaktadır. Gazzaniga için öykü anlatıcılığı aynı zamanda grup bağlılı̆̆ını artırarak, grubun yaşamını sürdürmesine de imkân sağlar. Öykü anlatıcılığı gruplarda dikkatin tek bir noktaya yöneltilmesini kolaylaştırmakta ve eski kabilelerin ortak değerler etrafında toplanmasına öncülük etmektedir. Öykünün olmadığı grupların soyu tükenirken, öykü anlatıcılığını sürdüren grupların hayatta kalması ve gelişmesi bunun bir göstergesi olarak sunulmaktadır (Gazzaniga, 2012, s.206).

Denning'e göre ise öykü anlatıclı̆̆ doğal, kolay, eğlendirici ve enerji verici olarak tanımlanmaktadır. Öyküler insanların karmaşalarının giderilmesine yardımcı olmakta, algıları güçlendirmekte ya da değiştirebilmektedir. Denning aynı zamanda öykülerin insanların kendilerini farklı bir ışık altında görebilmelerine olanak sağladığını ifade etmektedir (2001 s.17).

Edebiyat ve evrim üzerine çalışan Avustralyalı bilim insanı Brian Boyd da öykü anlatıcılığının zihin gelişimine katkıda bulunduğunu belirtmektedir. Boyd'a göre bir sanat eseri zihin için bir oyun parkı olarak görülmekte, öykülerin de oyun parkları gibi eğlence içerdiğini ifade etmektedir. Öykü üretmenin bir miktar zihinsel zorlama gerektirdiğini vurgularken "oyun parklarının vücut kaslarını geliştirmek için eşsiz firsatlar sunduğunu, öykü anlatıcılığının da beyin kaslarını geliştirdiğini" $(2009$, s.15) metaforik olarak göstermektedir.

Daniel Pink insan beynini sağ beyin ve sol beyin olmak üzere ikiye ayırır. Sol beyin dil, mantık ve sayılarla ilgildir ve sağ beyin duygular, duygudaşlık, yaratıcı düşünme ve görüntülerle ifade edilmektedir. Pink, insanlık tarihini Tarım Çağı, Sanayi Çağı, Bilgi Çağı ve Tasarım Çağı şeklinde dört bölüme ayırır. Daha önceki çağlar çiftçiler, fabrika işçileri ve bilgi çalışanları (doktor, eczacı, mühendis, mimar, bilim insanı, muhasebeci ve akademisyenler gibi sermayesi bilgi olanlar) gibi sol beyin yönetiminde olan dönemler iken, Tasarım Döneminin yaratıcılarını, tasarımcılar ve öykü anlatıcıları gibi sağ beyin kullanıcılarının etkin olduğu bir dönem olarak tanımlar. 21. yüzyılda öykü anlatıcılığı herhangi bir iş dalındaki herkesin uzmanlaşması 
gereken bir yetenek olarak görülür. Dünyada kalan sol beyin iş yöneticileri bile şirketlerini, ürünlerini ve hizmetlerini tanıtmak için sağ beyin öykü anlatıcılarına ihtiyaç duyar. Pink, geleceğin farklı zihin yapısına sahip insanlara ait olacağını belirtmekte, bunları da mucitler, öykü anlatıcıları ve bütüncül sağ beyin düşünürleri şeklinde kurgulamaktadır (2006, s.49).

Jonas Sachs'a göre internetin ve sosyal medyanın ortaya çıkışı ile insanlar öykü anlatıcısı köklerine dönmüştür. İnsanlık tarihinin büyük bir bölümünü oluşturan sözlü geleneği, son yüzyılda ortaya çıan yayıncllık dönemi ile karşılaştırmaktadır. Sachs'a göre öykü anlatıcılığının evrimi sözlü gelenekle başlayıp yayın dönemi ile devam etmiş ve dijital dönemle sözlü gelenek köklerine geri dönmüştür. Sözlü gelenekte insanlar ateşin etrafına oturup öyküler anlatmakta, öyküyü dinleyen herkes de o fikre katılmaktadır. Yayıncllık döneminde ise fikirler sadece üreticiye aitken, dijital dönemde tekrar herkesin fikir sahibi olduğu bir döneme geri dönüş yaşanmaktadır. Böylece fikirler düzenlenebilir, paylaşlabilir, yorumlanabilir ve beğenilebilir bir hal almaktadır (Sachs, 2012, s.57). Mesaj açısından bakıldığında ise sözlü dönemde mesajlar sosyalleşmeyle yayılmaktadır. Bir öykü birine anlatılır, o bir başkasına anlatır ve bu şekilde devam eder. Yayıncılık döneminde kişi ya da yayıncı mesajı aynı anda çok kişiyle paylaşır. Dijital dönemde mesajlar yine sosyal ağlarla paylaşılmakta ancak paylaşım hızı anlık olmaktadır. Bir anda mesajlar pek çok kaynaktan pek çok kişiye iletilip, geri besleme alınabilir (Sachs, 2012, s.58).

Gottschall öykü anlatıcılığının geleceği konusunda 'World of Warcraft' gibi çevrimiçi oyunlara dikkat çeker. Bu ve benzeri oyunlarda oyuncular başka oyuncuların da katıldığı karmaşık etkileşimli karakterlere dönüşürler. Bununla birlikte bu oyuncular bir topluluk ruhunu da paylaşmaktadır. Özellikle insanın yaşadığı dünyanın sıradan olduğu ortamlarda, böyle bir alternatif gerçeklik dünyası cezbedicidir (2012, s.240). Gottschall, insanların en derin ahlaki inançlarının ve değerlerinin öyküler ile değişebildiğini gösteren çeşitli çalışmalara dair örnekler verir. Bu çalışmalarda, farklı ırklardan insanların öykülerde ve filmlerde canlandırılmasının insanların o ırka karşı bakış açısını değiştirebildiğini ortaya çıkarmışlardır. Melanie Green ve Timoty Brock tarafından yapılan başka bir çalışmada da öykü dünyasına girmenin, radikal bir şekilde bilginin işlenme tarzını değiştirdiği öne sürülmektedir. Green ve Brock'un çalışmasında insanların öykünün daha fazla içine girmesiyle, onları bir o kadar değiştirdiği gösterilmektedir (2000, 
s.704). Öykünün içine daha fazla giren insanlar öykü içindeki hataları, tutarsızlıkları daha az görmekte, bu da öykülerin insanların eleştirel yanlarını da törpülediğini göstermektedir. İnsanlar kurgusal olmayan bir şey izlediklerinde, dinlediklerinde ya da okuduklarında genellikle eleştirel ya da şüpheci davranabilmekte ancak öykü sırasında bu eleştirel ve şüpheci zırh kaybolmaktadır. Öykülerle birlikte insan duygusal olarak sürüklenmekte ve savunmasız kalmaktadır (Gottschall, 2012, s.249).

Tüm bu tanımlamalar ışı̆̆ında çalışmada öykü anlatıcılığı, futbol kulüplerinin web sitelerinde aktarmış oldukları öyküler üzerinden değerlendirilmeye çalışılmaktadır. Çalışmada amaçlanan, öykü ve öykü anlatıcılığı unsurlarının futbol kulüplerinin kendilerini ifade ediş biçimlerine nasıl yansıdığıdır. Bunun yanı sıra futbol kulüplerinin taraftarlarıyla kurdukları iletişimde yer alan futbol, tarih ve kuruluş anlatısı yorumlanmaktadır.

\section{Öykü Anlatıcılığı ve Futbol: ‘Dört Büyükler'in İnternet Sitelerinde Aktarılan Öykülerin İncelenmesi}

Endüstriyel futbol olarak tanımlanan günümüz spor anlayışı ticarileşmenin en önemli çıtılarından biri olarak görülen fark yaratabilmeyi merkeze alarak iletişim ve marka çalışmalarını futbol kulübünün kendi dinamiklerine hizmet edecek şekilde konumlandırmaktadır. Bu bakış açısıyla tıpkı kurum ve markalarda olduğu gibi futbol endüstrisi de pazar ve rekabet gibi unsurları gündemine taşımaktadır. Bu nedenle futbol kulüpleri gerek taraftarlarında gerekse ülke ya da dünya kamuoyunda iyi bir izlenim yaratabilmek, marka değeri oluşturabilmek, saygın bir imaj dizayn edebilmek adına öykü anlatıcılığının gücünden faydalanmaktadır.

Futbolun modern bir oyun olarak ortaya çıkmasından sonra birçok değişimin yaşandığı ve bu değişim sürecinde pek çok farklı faktörün etkili olduğu kabul edilmektedir. Bu dönem içerisinde özellikle tüketim kültürünün ve yaşam tarzının kitlelere benimsetilmesinde, kitleleri etkileme gücü yüksek olan futboldan faydalanılmıştır. Hedef kitlelerinde güçlü bir imaj yaratmak isteyen futbol kulüpleri kendi öykülerini taraftarlarına aktarmakta ve marka değeri yaratama konusunda öykü anlatıcılığını bir araç olarak konumlandırmaktadır.

Görülen o ki futbol kulüpleri arasındaki rekabet sadece maç esnasında değildir. Kulüpler aynı zamanda yeni taraftar kazanmak, mevcut taraftarları 
korumak ve taraftarları ekonomik olarak spor kulübüne bağlamak için de rekabet etmektedir. Başarının şampiyonluk olarak ölçüldüğü spor dünyasında bazı takımlar çok sayıda şampiyonluk yaşamamış olsalar dahi taraftarlarının takımı desteklemeye devam etmesi amaciyla birçok faaliyette bulunmaktadırlar. Bunu sağlamak için spor yöneticileri kulüplerini bir marka gibi yönetmekte ve sportif başarıdan bağımsız olarak hedef kitlelerinin davranışlarını etkilemek için güçlü birer marka yaratmaya çalışmaktadır (Gladden ve Funk, 2002). Takım taraftarları ve geleneksel müşteriler karşılaştırıldığında, takım taraftarlarının takımlarına olan ilgi ve bağlllıklarının, müşterilerin markalara olan ilgi ve bağl1lıklarından çok daha güçlü olduğu kabul görmektedir (Parker ve Stuart, 1997, s.7; Abosag ve ark, 2012, s.1249).

Çoğu futbol kulübü de marka iletişimini belli değerler ve öyküler üzerine inşa etmektedir. Taraftarlar da bu öykülerin ve değerlerin birer parçası olmaktadır. Gerek dünyada gerekse Türkiye'de bunu kanıtlayacak birçok örnek siralamak mümkündür. Barcelona Spor kulübü yıllar boyunca Katalan kültürünün bir sembolü olmuştur. Primo de Rivera ve Franco gibi diktatörlerin döneminde dahi devrimci ruhu temsil etmişlerdir. Dinamo Zagrep takımı Hırvatistan için Yugoslavya' dan kopuşun ve bağımsızlığın sembolü olarak görülmektedir. Yunanistan'da AEK kulübü 1924'de Türkiye'den Yunanistan'a techir edilen Rumların dayanışma ve birlikteliklerinin öyküsünü taşımaktadır. Leichester City kulübünün öyküsi de başka bir örnek olarak karşımızda durmaktadır. Leichester City bir bakıma dev Calud'a karşı mücadele veren Davut'un öyküsünü bünyesinde taşımaktadır. Görülen o ki, her kulübün kendi değerlerini yansıtan öyküleri vardır ve bu öyküler üzerinden taraftarlarıyla duygusal bağlar yaratmakta ve devam ettirmektedir.

Fog ve arkadaşları bu tür öyküleri çekirdek öyküler olarak adlandırmakta ve çekirdek öyküyü markanın can suyu şeklinde tanımlamaktadır. Markanın yaşaması için çekirdek öykünün tüketicinin zihninde bırakacağı etkinin çok önemli olduğu vurgulanmaktadır. Çünkü marka ve tüketicisi arasındaki bağ çekirdek öykünün oluşturduğu düşünülmektedir. Çalışmada da buna dayanarak yapılan incelemeler sonraki bölümlerde detaylandırılmaktadır.

\section{Yöntem}

K. B. Jensen'e göre internet özel bir analitik nesne olarak vurgulanmakta ve kendi verisini kendisi üretmektedir. Jensen internet çalışmalarında temel 
yöntemleri şu şekilde incelemektedir; niceliksel olanlar (çevrimiçi ya da çevrim dışı anket, web kullanım bilgisi ölçüm laboratuvar deneyleri ya da arama motoru içerik çözümlemeleri) ve niteliksel olanlar (çevrim içi ya da çevrim dışı derinlemesine görüşmeler, katılımlı gözlem, söylem analizi ve tarihsel, estetik eleştiri) (2011, s. 48). Bu çalışmada da veri toplama yöntemi olarak nitel içerik çözümlemesi kullanılmaktadır. Bu yöntem belli sözcüklerin, kavramların, temaların, ifadelerin, metinlerin içindeki cümlelerin varlığın belirlemek ve bu varlığın objektif bir şekilde ölçümü için kullanılmaktadır. İçerik analizi sosyal bilimcilere arşivlerden, belgelerden, gazetelerden, sinema, dizi gibi çeşitli görsel dokümanlardan, çeşitli kitle iletişim araçlarından elde edilen bilgilerin bir anlam kazandırılması amacyyla sistematik olarak incelenmesidir. Daha somut bir ifade ile belirli konular hakkında mahkeme kararlarının incelenmesi, gazete haberlerinin incelenmesi, çeşitli tarihler arasında tarih arşivlerinin incelenmesi, televizyon görüntülerinin nasıl yansitıldığının incelenmesi, romanların incelenmesi vb. gibi konular örnek gösterilebilir. İçerik analizi teknikleri son yıllarda artan bir şekilde internet sayfalarındaki içeriği analiz etmek için de kullanılmaktadır (Herring, 2009, s.234).

Söz konusu çalışmada Türkiye'nin dört büyük spor kulübü olarak kabul edilen Beşiktaş JK, Fenerbahçe SK, Galatasaray SK ve Trabzonspor' un resmi web sayfalarının Türkçe sürümünü temel alınmıştır. 01-09 Nisan 2019 tarih aralığında incelenen bu sayfalarda çeşitli sekmeler altında öykü unsurlarının izi sürülmüştür. Bunun sonucunda kulüplerin resmi web sayfalarında çeşitli öykülerin olduğu görülmüş, öyküler belli kategoriler üzerinden incelenmiştir. Kategorilerin oluşturulmasında Fog ve arkadaşlarının çekirdek öykü modeli kullanılmıştır. Buna göre öykünün temelini oluşturan dört temel unsur "mesaj, çatışma, karakterler ve olay örgüsü" üzerinden değerlendirmeler yapılmıştır. Bu unsurları taşımayan metinler çalışmaya dahil edilmemiştir. Bunun yanı sıra futbol kulüplerinin web siteleri aracılığıyla aktarmış oldukları öykülerle birlikte ön plana çıkarmaya çalıştıkları arketip özellikleri de araştırma kapsamı içerisinde yer almaktadır.

Buna göre araştırma sorularını şu şekilde sıralamak mümkündür;

1. Futbol kulüplerinin resmi web sitelerinde 'öykü anlatıcllı̆̆ı' unsurları kullanılmakta mıdır?

2. Türkiye'de 'Dört Büyükler' olarak kabul edilen Beşiktaş JK, Fenerbahçe SK, Galatasaray SK ve Trabzonspor kulübü web sitelerinde 
Fog ve arkadaşlarının çekirdek öykü modeline uygun öykü anlatımlarına rastlamak mümkün müdür?

3. Türkiye'de 'Dört Büyükler' olarak kabul edilen Beşiktaş JK, Fenerbahçe SK, Galatasaray SK ve Trabzonspor kulübü web sitelerinde, kendilerini taraftarlarına hangi arketipsel özellikleri ön plana alarak seslenmekte ve öykülerini ulaştırmaktadır?

\section{Evren ve Örneklem}

Araştırma evreni spor iletişiminin çok önemli bir alanı olan futbol kulüpleridir. Çalışma sadece şampiyon olmuş ve Türk futbolunda ‘Dört Büyükler' olarak adlandırılan kulüplerle (Beşiktaş JK, Fenerbahçe SK, Galatasaray SK ve Trabzonspor kulübü) sınırlı tutulmuştur. Bahsi geçen kulüplerin resmi web sayfaları üzerinden aktarılan mevcut öykülere bakılmış, burada yer alan anlatılardaki mesaj, karakter, çatışma ve olay örgüleri değerlendirilmiştir.

\section{Bulgular ve Yorum}

\section{Beşiktaş JK'nin Resmi Web Sitesinin Öykü Anlatıcılı̆̆ı Açısından Incelenmesi}

İlk olarak Beşiktaş spor kulübünün resmi internet sayfası olan www.bjk.com.tr Türkçe sürümü incelenmiş ve internet sayfasında öykü anlatıcılığ unsurlarına uygun öyküler aranmıştır. Resmi internet sitesinde 'Kulüp' başlığı altında Fog'un hikâye tanımına uygun hikâyelerin olduğu gözlemlenmiştir. 'Kulüp' başlığının altında 'Tarihçe' kısmında yer alan metinlerin çalışmaya konu olan öykü tanımına uygunluk taşıdığı görülmektedir. Bu bölüm altında 'Beşiktaş'ın Kuruluşu', 'Renkleri ve İlk rozeti', 'Kara Kartallar Efsanesi', 'Beşiktaş ve Futbol', 'Savaş Yılları', 'Yeni Lig'in Kuruluşu', 'İlk Yılda İlk Şampiyonluk', 'Ahmet Şerafettin Bey', 'Süleyman Seba', başlıklarının altında toplam 10 öykü tespit edilmiştir. Bu öykülerden çalışmaya konu olan Fog ve arkadaşlarının modeli doğrultusunda incelenebilecek öykülerden kesitler Tablo 2'de yer almaktadır. 
Tablo 2. Beşiktaş JK'nin Resmi Web Sitesinde Yer Alan Öykü Başlıkları ve Kesitleri

..."1902 sonbaharında Beşiktaş Serencebey Mahallesi'nde, o zamanın Medine Muhafızı olan Osman Paşa'nın konağının bahçesinde, 22 kişilik genç grup, haftanın bazı günlerinde toplanıp jimnastik hareketleri yapmaktaydı."...

Kuruluş "1903 Mart'ında ise özel bir izinle Bereket Jimnastik Kulübü kuruldu."...

"Siyasi olaylar yatıştıktan sonra iyi bir eskrim hocası olan Fuat Balkan ile başta güreş ve halter sporlarını yapan Mazhar Kazanc1, Serencebey'de jimnastik yapan gençleri bularak birlikte spor yapma fikrini kabul ettirdi. Fuat Balkan, Ihlamur'daki evinin altındaki yeri, kulüp merkezi yaptı ve Bereket Jimnastik Kulübü'nün adı Beşiktaş Osmanlı Jimnastik Kulübü olarak değiştirildi"...

..."Bizler de bir rozet yaptırmalı ve Kulübümüzde spora devam eden her azayı bu rozeti taşımaya mecbur tutmalıyı" dedi. Toplantının sonunda rozette yer alacak

Beşiktaş̧'ı kulüp renkleri kararlaştırıld. Tabiatın bütünüyle birbirine zıt iki ana rengi kulüp Renkleri renkleri olarak seçildi: Siyah ve Beyaz...Beşiktaş'ın ilk rozetinin yapıldığı tarih, ve İlk Rozeti Fransız mektebindeki rozetlerden esinlenerek miladi yıl olarak "1906" yazıldı. Üstte Arap harfleriyle "Beşiktaş" yazarken, sağda "J", solda "K" harfleri yer aldı. Rozetin arka yüzünde "Konstantinopolis"te yapıldığı yazılıdır ve iç tarafında rozeti yapan ustanın mührü yer almaktadır"...

“19 Ocak 1941 Pazar günü Semih Duransoy'un hakemliğini yaptığı Şeref Stadı'ndaki maça Beşiktaş şu kadro ile çıkar: Faruk, Yavuz, İbrahim, Rıfat, Halil, Hüseyin, Şakir, Hakkı, Şükrü, Şeref, Eşref. O sezon bütün maçlarda olduğu gibi, Takımımız yine muhteşem bir oyun ortaya koyar. Maçın ikinci yarısının ortalarıdır. Beşiktaş takımı farklı önde olmasına rağmen rakip kaleye bitmek tü-

Kara kenmek bilmeyen hücumlar gerçekleştirmektedir. İşte o sıralarda Beşiktaş'ın akın Kartallar yönü olan Şeref Stadı'nın Atatürk panosu bulunan tarafındaki tribününden bir ses Efsanesi yükselir: “Haydi Kara Kartallar. Hücum edin Kara Kartallar"... Şeref Stadı'nı dolduran binlerce taraftar ve maçı takip eden gazeteciler, çınlayan sesle donup kalmıştır. Son derece isabetli bir benzetmedir o anda yapılan. O sezon rakiplerini ezip geçen Beşiktaşlı futbolcuları "Kara Kartal"dan, oynadıkları futbolu "Kara Kartal gibi hücum etmek"ten başka bir şekilde tarif etmek mümkün değildir...

..."1911 Ağustos'unda Valideçeşme futbol takımının başkanı ve kurucusu olan

Beşiktaş Ahmet Şerafettin Bey (Şeref Bey) futbolcularıyla Beşiktaş Kulübü'ne katıldı. Beşikve taşlı gençlerin kurduğu futbol takımlarını tek bir çatı altında toplamayı amaç ediFutbol nen Şeref Bey'in girişimleri sonucu, Basiret Kulübü de Beşiktaş'a katıldı. Bu şekilde Futbol Şubesi, resmi olarak Kulüp'te faaliyete başladı."...

“İstanbul'da düşman işgalinin olduğu yıllarda çeşitli sıkıntılar çekildi. Daha önce bir kilisenin binasına taşınan kulüp malzemelerinin bir kısmı Rumlar'ın elinde

Savaş Yılları yağma olmaktan kurtarılıp, Akaretler'de başka bir binaya nakledildi. Bir taraftan düşmanla yapılan Milli Mücadele'ye yardım edildi. Diğer taraftan da futbol takımı Şeref Bey tarafından tekrar güçlü hale getirildi."...

\begin{tabular}{ll}
\hline İlk Yılda & ...'Grubunda bütün maçlarını kazanan Beşiktaş, finalde diğer grubun birincisi \\
İlk & Darüşşafaka ile karşı karşıya geldi. 23 Temmuz 1920'de oynanan bu maçı Siyah-Beyazlı \\
Şampiyonluk & takımımız, 2-1 kazanarak tarihimizdeki ilk şampiyonluğumuzu elde etti.”... \\
\hline & “Mimari planları Mimar Vietti Violi , Mimar Şinasi Şahingiray ve Mimar Fazıl \\
& Aysu tarafından hazırlanmış olup, II. Cumhurbaşkanı İsmet İnönü devrinde ve \\
İnönü & Lütfi Kırdar'ı İstanbul Valiliği ve Beden Terbiyesi Bölge Başkanlığı zamanında \\
Stadı & $\begin{array}{l}\text { yapılmış ve 19 Mayıs 1947 yılında açılmıstır. 1950'li yıllarda stadyumun arka tara- } \\
\text { fında bulunan gazhane ve havagazı fabrikası daha sonraki yıllarda yıkılarak yeni }\end{array}$ \\
& açık tribünler inşa edilmiştir.”... \\
\hline
\end{tabular}




\begin{tabular}{|c|c|}
\hline $\begin{array}{l}\text { Ahmet } \\
\text { Şerafettin } \\
\text { Bey }\end{array}$ & $\begin{array}{l}\text {..."O doğma büyüme Beşiktaş'ın çocuğu Ahmet Şerafettin'dir.”... } \\
\text { “Şeref Bey futbolcudur, idarecidir, yurt dışında maç yönetmiş (Viyana'da) ilk } \\
\text { futbol hakemidir... Bunların yanında çok iyi derecede Fransızcası olan, çok okuyan, } \\
\text { çok yazan bir entelektüel, hayatını gençliğin eğitimine ve spora adamıs, Cumhuri- } \\
\text { yet gençliğine inanan, güvenen bir eğitim adamıdır."... }\end{array}$ \\
\hline $\begin{array}{l}\text { Süleyman } \\
\text { Seba }\end{array}$ & $\begin{array}{l}\text {...1947 yılında İnönü Stadyumu'nun açlış maçında İsveç'in AIK takımına attı̆̆ } 1 \\
\text { gol, bu stadyumda bir Türk futbolcusunun attığı ilk gol olarak tarihe geçti. } 1950 \\
\text { yılında Beşiktaş Futbol takımının Amerika'ya davet edilmesiyle, babasını üzmek } \\
\text { pahasına, okulunu bırakarak, çok sevdiği Beşiktaş'la bir ay süreyle Amerika'ya } \\
\text { gitti. Beşiktaş'a yıllarca başarıyla hizmet eden Süleyman Seba'ya "Onursal } \\
\text { Başkanlık" unvanı verildi ve camianın daima birleştirici gücü olarak görüldü..... }\end{array}$ \\
\hline
\end{tabular}

Fog ve arkadaşlarının çekirdek öykü modeline göre öykülerde olması gereken unsurlar, mesaj, çatışma, karakterler ve olay örgüsüdür. Beşitaş JK'nin resmi web sitesi üzerinden yapılan inceleme dahilinde 10 öykünün de bu unsurları içerdiği görülmektedir. Kulübün kuruluşu, Fuat Balkan'n Ihlamur'daki evinin altındaki yeri kulüp merkezi yapması ve Bereket Jimnastik Kulübü adının Beşiktaş Osmanlı Jimnastik Kulübü olmasına dayandırılmakta, tabiatın bütünüyle birbirine zıt iki ana renginin kulübün renkleri olan "Siyah ve Beyaz" olarak seçilmesiyle devam eden bir anlatı göze çarpmaktadır. Beşiktaş'ın 'Kara Kartallar' olarak anılmasının öyküsi, savaş yıllarında Milli Mücadeleye destek olunması, Şeref Bey'in kulübü savaş sonrasında tekrar güçlü hale getirmesi, İnönü Stadı gibi taraftarlar açısından da hassas olan hususlar öykü örgüleri içerisinde vurgulanmaktadır. Özellikle kahramanlık, asalet, şerefli olma gibi duygusal çekicilik içeren unsurlar, Şeref Bey, Süleyman Seba gibi kulüp için efsaneleşmiş isimlerle birlikte öyküleştirilmektedir.

Öykülerdeki karakterler incelendiğinde 'kahraman' arketipinin ön plana çıtığı tespit edilmektedir. Bu bağlamda özellikle Ahmet Şerafettin Bey'in savaş yıllarında verdiği mücadele ile Beşiktaş kulübü arasında bağ kurulması dikkat çekicidir. Öyküye göre 1903 yılında kurulan kulüp dönemin İngiliz, Rum, Ermeni takımlarını yenerek dize getirmiş ve bir uyanış gerçekleştirilmiştir. Sonrasında Çanakkale'de şehit düşen Şair Kâzım ve Asım ile Kafkas cephesinden dönemeyen Dr. Ali, Dr. Mehmet ve Rıdvan'ın yokluğu yüzünden Beşiktaş JK'nin kapanması gündeme gelmiş, bu sırada yeni bir kahramanın çıkmasıyla- Ahmet Şerafettin Bey- takımı küllerinden yeniden kurmuş, Beşiktaş'ın kaptanı ve teknik direktörü olmuştur. Beşiktaş'ın şehidi ve feda sözü ile bilinen Ahmet Şerafettin Bey ile ilgili öyküye dair bir kesit şu şekilde aktarılmaktadır: 
“İmir Bölgesi ile Ankara Bölgesi'nin yapacağı maçın hakemliğini Şeref Bey' e teklif ederler. Seve seve kabul eder. Alkışlar arasında sahaya çıkar... Maçın ilk yarısının son dakikalarmda yığılır kalır yeşil sahaya... Yanına koşup gelenlere: "Bir şeyim yok...Merak etmeyin.. Herhalde heyecandan tansiyonum düşmüş olacak... Halftaymda dinlendikten sonra bir şeyim kalmaz..." diye cevap verir... Hastalığına kulak asmaksızın Ankara'da kalan Şeref Bey, Çırağan'ın bahçesini Beşiktaş kulübüne mal etme yolunda önemli mesafe alır. Bazı gerekli imzalarn tamamlanmasinn ardindan İstanbul'a döner. Ancak ihmal ettiğ i hastalığı oldukça ilerlemiştir. Artık ayakta duramamaktadır. Köyiçindeki evinde yatağa serilir. Yapılan testlerin sonucunda Şeref Bey'in hastalığına kesin teşhis konur... Bu teşhis ne yazık ki kanserdir... 39 yaşındayken, yakalandiğı bu amansız hastalikla 12 ay mücadele ettikten sonra Beşiktaş için harcanan ömür sona gelmiştir. Ölüm döşeğinde ise, o unutulmaz diyalog yaşanır. Doktor Enver Bey, "Hastasin biliyorsun.. Dinlenmen gerekirken hala Beşiktaş hala Beşiktaş. Beşiktaş seni öldürecek bu genç yaşta dostum" der. Şeref Bey hasta yată̆ından doğrulur, feda" der..

Bu öykü aynı zamanda Beşiktaş JK'nın yıllarca mottolaşan ve sonraki yıllarda taraftarların da dahil edildiği 'Feda' iletişim kampanyasının da sloganı olarak kullanılmıştır.

Öykülerde 'çatışma' unsuru ise öncelikle yabancı takımlarla, sonrasında ise diğer Türk takımlarıyla yapılan mücadeleler üzerine kuruludur. Çatışmadan zaferle çıkmak kadar şerefli bir şekilde yenilmek de başarı olarak gösterilmektedir. Bu değer Süleyman Seba ile ilgili öyküde "Şerefli ikincilik, kirli şampiyonluktan daha iyidir" deyişi ile vücut bulur. Öykülerdeki olay örgüleri incelendiğinde 'yeniden doğuş, macera, trajedi' gibi temalar göze çarpmaktadır. Öykülerde kahramanların fedası ile kara kartal yeniden canlanmaktadır. Beşiktaş'ın renkleri, Kara Kartallar efsanesi gibi öykülerin aynı zamanda bir değer ve kulübün kurumsal kimliğini oluşturma amacına yönelik olduğunu da söylemek mümkündür.

Bir bütün olarak bakıldığında Beşiktaş JK'nin resmi web sayfasındaki öykülerde yansitılan Beşiktaşlı olma 'şeref, hak, tutku, bağhllık, halkın takımı olma' gibi değerlerle ve“Şerefimizle Oynarırz. Hakkımızla Kazanırız. Halkın Takımıyız. Özümüzden Güç Alırız. Tutukuyla Bă̆lıyız" mesajiyla pekiştirilmektedir. 


\section{Fenerbahçe SK'nın Resmi Web Sitesinin Öykü Anlatıcılı̆̆ı Açısından Incelenmesi}

Fenerbahçe Spor kulübünün sayfası https://www.fenerbahce.org/ incelendiğinde 'Kulüp' sekmesinde 'Tarihçe' ve 'Atatürk ve Fenerbahçe' başlığı altında toplam 19 öykünün aktarıldığı görülmektedir. Hikâyelerin Fenerbahçe SK'nın kuruluşu, kulübün geçirdiği evreler ve mücadeleler ile ilgili olduğunu söylemek mümkündür. Bu öykülerden çalışmaya konu olan Fog ve arkadaşlarının modeli doğrultusunda incelenebilecek öykülerden kesitler Tablo 3'de yer almaktadır.

Tablo 3: Fenerbahçe SK'nın Resmi Web Sitesinde Yer Alan Öykü Başlıkları ve Kesitleri

Kuşdili Çayırında İlk Futbol Oyunu (1823)

Kadıköy ve Fenerbahçesi (1884)

Kadıköy Football Association (1890)

Black StocKings FC Kuruluyor (1899)

Fenerbahçe'nin Gerçek Kuruluş Y1lı (1899)

Kadıköy'de Kuruluşu Bekleyiş (1900)

Tarihçe $\quad$ Fenerbahçe'nin Gerçek Kuruluş Y1lı (1901)

İstanbul'da İlk Futbol Ligi Günleri (1906)

1907 Resmi Kuruluşa Doğru

Fenerbahçe Futbol Takımının İlk Kadrosu Kuruluyor (1907)

Kuruluşu Tescil Olunan İlk Türk Kulübü; Fenerbahçe (1908)

İstanbul Şampiyonluğu Ligi (1908)

Kuşdili Spor Kulübünün Bünyeye Katılması (1910)

Fenerbahçe'nin İlk Rozeti (1910)

İlk Namağlup Şampiyonluk (1911)

İstanbul'da İşgal Yılları (1920)

İşgal Yıllarında Gurur; Fenerbahçe (1921)

..."Fenerbahçe'nin işgal kuvvetlerine karşı en büyük zaferlerinden biri de

"General Harington Kupası" maçıdır. Maç 29 Haziran 1923 günü, Taksim

Stadı'nda çok büyük bir seyirci topluluğu önünde oynanmıştı. Düşünsenize;

General bir sabah uyandığınızda hiç tanımadığınız, belki üniformasını daha önce hiç

Harington görmediğiniz, başka başka diller konuşan bir sürü silahlı adam köşe başlarını

Kupası tutmuş, ordunuzun silahlarına el koymuş, kirli çizmeleriyle o kutsal topraklarınızı çiğniyor"...

...'Türkiye Cumhuriyeti'nin kurucusu Mustafa Kemal Atatürk de Fenerbahçeli'ydi. Atatürk, 10 Ağustos 1928 günü, 3-3 berabere biten Gazi Kupası ma-

Atatürk ve çından sonra üçü Galatasaraylı ve ikisi Fenerbahçeli olan beş kişinin önünde

Fenerbahçe $\quad$ aynen şunları söyledi: "Burada üçe üçüz... Çünkü ben de Fenerbahçeliyim!"... 
Fenerbahçe SK'nın resmi web sitesi üzerinden incelenen 'Tarihçe' başlığı altında yer alan ve kronolojik olarak Fenerbahçe kulübü açısından önemli bazı tarihler ve bu tarihlerde gerçekleşen bazı önemli olaylar öyküleştirilmiş, öykülerde özellikle İstanbul'un işgali sırasında Fenerbahçe takımının nasıl bir kahramana dönüştüğü ve halka moral verdiği anlatılmaktadır. Bu öykülerde Fenerbahçe SK'nın güçlü bir karakter olarak konumlandırıldığı görülmektedir.

“Evet, İstanbul artık o eski İstanbul değildi. Acr günler gelip çatmış, herkes üzgün, herkes kendi vatanında sürgün gibiydi. İşgalcilerle birlikte yaşamak zorunda olan talihsiz İstanbul halkma, o güne kadar yaşadıkları, ne gıdasızlik, ne susuzluk, ne elektrik kesintileri, ne de hiçbir şey, "İşgal İstanbul'u "na tankklk etmek kadar onlara acı vermemişti. İste bütün bu olumsuz şartlar altında halkın morali için mutlak bir desteğe ihtiyacı vardı ki, işte bu ihtiyaç duyduğu güç, ona kendi öz bağrından çıkarttı̆̆ı takımı tarafindan "Fenerbahçe"si tarafindan verilecekti. İşgal yıllarındaki gurur; Fenerbahçe".

Öykülerde aynı dönemler içerisinde Fenerbahçe'nin işgal kuvvetleri takımları karşısındaki galibiyetlerinin aynı zamanda halkın intikam duygularına seslenerek, milli duyguları yücelten ve halka teselli veren kahraman arketipiyle özdeşleştirildiğini de söylemek mümkündür.

“Türk takımları işgalci ekiplerle 5 yılda 50'sini Fenerbahçe'nin oynadığı toplam 80 maç yapıyor, işgal kuvvetleri takımlarına karşı kazanılan galibiyetler ise Türk takımlarm gönüllerde yüceltiyordu. Bu nedenle futbol Isstanbul'da büyük kitleleri kendine çekerken, Türk takımlarının özellikle de Fenerbahçe'nin, başta General Harrington Kupası (29 Haziran 1923) olmak üzere işgal kuvvetleri takımları karşısında elde ettikleri tüm galibiyetler, İstanbul halkının intikam duyguları içindeki milli duygularmı şahlandıran ve yaralı gönüllerine teselli veren yegane olay haline dönüşüyordu."

Öykülerdeki çatışma unsuru incelendiğinde ise Fenerbahçe SK'nın rakibi işgal kuvvetleri olarak gösterilmekte, işgal kuvvetleri ile Fenerbahçe kulübü arasındaki mücadele Fenerbahçenin kahramanlığ 1 şeklinde yüceltilmektedir. Buna dair bir öykü şu şekilde aktarılmaktadır;

"İstanbul işgal altındayken Fenerbahçeliler, Kurbağahdere kenarmda kulüp binasının önündeki iskeleye yanaşan motorlarla Anadolu'ya silah kaçırmaktaydllar. Fenerbahçe kulübünün kayıkhanesi bir silah ve cephane deposu 
haline getirilmişti. Geceleri gizlice bu kayıkhanenin önündeki ahşap iskeleye yanaşan motorlar buradan yüklenip, gizlice Moda koyuna açıllyor, oradan İzmit'e geçerek Anadolu'ya silah ve cephane götürüyorlardr. Fenerbahçe kulübünün bu "zararlı(!) faaliyeti" İşgal Orduları Başkomutanliğı tarafindan haber alınmıs, ancak bunun farkına varan Fenerbahçeliler kayıkhaneyi derhal boşaltarak cephaneyi çeoredeki üye ve sporcu evlerine taşımışlardı. Kulübü basan işgal kuvvetleri birlikleri ortada delil bulamamışlard. Ancak yine de Başkomutanlık tarafindan Fenerbahçe kulübüne süngülü bir müfreze blrakılmıs ve Fenerbahçe kulüp binası haftalarca işgal altında tutulmuştur"

Öykülerde Atatürk'ün Fenerbahçeli olduğunun ispatının ön planda olması dikkat çekicidir. Bununla birlikte İsmet İnönü ve Lozan Anlaşması ile Fenerbahçe'nin General Harrington Kupası'nı kazanması arasındaki ilişki İsmet Paşa'nın Lozan'dan yolladığı tebrik telgrafı ile kurulmaktadır.

Öykülerdeki olay örgüsü ise anlatıların 'maceralar ve mücadeleler' üzerinden aktarımına dayanmaktadır. Özellikle Fenerbahçe SK'nın kendisinden kat kat üstün düşmanlarını yenebileceği gösterilmekte, bu olgu üzerinden vatanperverlik mesajı iletilmektedir. Fenerbahçe kulübünün logosunun ortaya çıkışı da duygusal çekicilik unsurlarının ön planda olduğu bir anlatıyla sunulmaktadır. Öykü anlatısına göre "logo üzerindeki mavi kalkan üzerinde sarı bant başkalarının bu İstanbul kulübü için hissettiği hayranlığı ve kıskançlığı anlatmaktadır. Fenerbahçe'nin kuruluşundan birkaç yıl sonra Hikmet isimli bir oyuncusu tarafından tasarlana logo üzerindeki mavi asaleti, beyaz saflığı ve açık fikirliliği, kırmızı aşkı ve Türk Bayrağını, yeşil ise başarıyı temsil etmektedir. Meşe yaprağı direnmenin, azmin ve gücün sembolü olarak tanımlanmaktadır.

Yapılan inceleme doğrultusunda Fenerbahçe SK'nın resmi web sitesi içerisinde yer alan öykülerde özellikle 'asalet, direnme, güçlü olma ve vatanseverlik' duygularını mesajlarda aktarıldığı görülmektedir.

\section{Galatasaray SK'nın Resmi Web Sitesinin Öykü Anlatıcılı̆̆ Incelenmesi}

Galatasaray kulübünün https://www.galatasaray.org/ incelendiğinde hikâyelerin de Ana Sayfada 'Tarihçe' sekmesinin altında bulunduğu görülmektedir. 'Galatasaray Nasıl kuruldu?', 'Renklerin Öyküsü', 'Illk Yıllar', 


\section{'Galatasaray Logosunun Kuruluşu', 'Galatasaray Şehitleri', 'Atatürk ve Ga- latasaray', ‘'̇lk Mabet Ali Sami Yen Stadı', 'Galatasaray Lisesi’ alt başlıkları altında toplam 8 öykünün konumlandırıldığı görülmektedir. Bu öyküler- den çalışmaya konu olan Fog ve arkadaşlarının modeli doğrultusunda in- celenebilecek öykülerden kesitler Tablo 4'de yer almaktadır.}

\section{Tablo 4. Galatasaray SK'nın Resmi Web Sitesinde Yer Alan Öykü Başlıklarn ve Kesitleri}

\begin{tabular}{|c|c|}
\hline $\begin{array}{l}\text { Galatasaray } \\
\text { Nasıl } \\
\text { Kuruldu }\end{array}$ & $\begin{array}{l}\text { “Türk Spor Tarihi'ndeki öncü olma özelliğini hiç kuşkusuz içinden doğduğu ve gene } \\
\text { öncü bir kurum olan Galatasaray Lisesi'nden (Mektebi Sultani) almıştır. Okul ile kulüp } \\
\text { arasındaki koparılmaz bağ, yadsınamayacak bir gerçeklik ve övünç kaynağıdır... II. } \\
\text { Beyazıt tarafından 1481'de kurulan mektep, adını kurulduğu bölgeden alır ve "Galata } \\
\text { Sarayı" olarak anılmaya başlar"... } \\
\text {..."Türk olmayan takımları yenmek"... } \\
\text {..."Ali Sami Yen'in Kaleminden Galatasaraylılık"... }\end{array}$ \\
\hline $\begin{array}{l}\text { Renklerin } \\
\text { Öyküsü }\end{array}$ & $\begin{array}{l}\text {..."Galatasaray Spor Kulübü'nün ilk renkleri kırmızı-beyazdır.”... } \\
\text {..."Biri, vişneye çalan koyuca tatlı bir kırmızı, öteki de, içinde turuncudan iz taşıyan tok } \\
\text { bir sarı. Tezgahtar, mahirane bir el hareketi ile kumaşların dalgalarını birleştirdi. Bir saka } \\
\text { kuşunun başı ile kanadının yarattığı renk güzelliğine benzer bir parlaklık hasıl oldu. } \\
\text { Ateşin içindeki renk oyunlarını görür gibi olmuştuk. Sarı-Kırmızı alevinin takımımız üs- } \\
\text { tünde parıldamasını tasavvur ediyor ve bizi derhal galibiyetten galibiyete götüreceğini } \\
\text { tahayyül ediyorduk.”... } \\
\text {..."Kuruculardan Bekir Sıtkı, söz konusu renklerin Gül Baba'nın II.Beyazıt'a verdiği sarı } \\
\text { ve kırmızı güllerden esinlendiğini ileri sürer"... }\end{array}$ \\
\hline İlk Yıllar & $\begin{array}{l}1905 \text { yılı Ekim ayında Galatasaray Lisesi öğrencilerinden Ali Sami Yen, Galatasaray Lis- } \\
\text { esi'nde Mehmet Ata Bey'in dersi sırasında arkadaşlarıyla konuşarak, yeni bir futbol } \\
\text { kulübü kurmaya karar verir... } \\
\text {...Ali Sami Yen ve arkadaşları, 1905'de Kadıköy'de bir Rum ekibiyle oynadıkları maça } \\
\text { isimsiz olarak çıkar ve maçı 2-0 kazanırlar. Maçların sonunda, kulübün ismi seyirciler } \\
\text { tarafından konur: “Galata Sarayı Efendileri”... }\end{array}$ \\
\hline $\begin{array}{l}\text { Galatasaray } \\
\text { Logosunun } \\
\text { Doğuşu }\end{array}$ & $\begin{array}{l}\text {...Arkadaşlarının kısaca Ayet olarak çağırdıkları Ayetullah, kendisi gibi bir dergi } \\
\text { çıkarmaya ve bu sayede Galatasaraylı ögrencilerin sesi olmaya meraklı olan arkadaşı } \\
\text { Şinasi ile Kara Kedi adını verdikleri bir dergi çıarmaktaydı... } \\
\text {...Ayet, Harf devrimi öncesinde kullanılan alfabenin G ve S’ye karşılık gelen gayın ve } \\
\text { sin harflerini ahenkli bir tasarım ile birlikte çizmiş, her zaman yaptığını yaparak, ortasına } \\
\text { da kendi dergisinin adını ve "logosunu”, o sevimli kara kedisini yerleştirmişti... } \\
\text {..."Galata" ve "Saray" kelimelerinin baş harflerinin çok şık bir tasarım ile istiflenerek bir } \\
\text { araya getirilmesinden oluşan- tabii ki kara kedisiz- bu amblemin kulüp yöneticilerine } \\
\text { gösterilmesi kararı verildi... }\end{array}$ \\
\hline $\begin{array}{l}\text { Galatasaray } \\
\text { Şehitleri }\end{array}$ & $\begin{array}{l}\text {...Bugünkü Galatasaray Lisesi'ne girer, ağaçların doğal bir koridor oluşturduğu yoldan } \\
\text { ilerlerseniz karşınıza çıacak olan Mektep binasının ana kapısına ulaşırsınız. İçeriye gi- } \\
\text { rin tüm Galatasaraylılar ve Galatasaraylı olmayanlar ve tarihin bir bölümüne tanık } \\
\text { olun... } \\
\text {...̇̇̇erdeki bu taş ve mermer salonda sizi "VATAN" ve "GALATASARAYLILIK" sevgisi } \\
\text { karşılayacaktır. Kapının tam karşısındaki bölümde yalın olmasına karşın görkemli bir } \\
\text { anıtta vatan uğruna şehit düşen Galatasaray Lisesi öğrencilerinin listesi yer almakta- } \\
\text { dır... }\end{array}$ \\
\hline
\end{tabular}




\begin{tabular}{|c|c|}
\hline & $\begin{array}{l}\text {..."Hiçbir lise Atatürk'ten böyle bir ilgi görmemiştir...Galatasaray, sadece 'Türkiye'nin' } \\
\text { Batı' ya açlan penceresi' değil, Atatürk devrimlerinin en önemlilerinden, belki de en } \\
\text { önemlisi laisizmin kilometre taşlarından biri olmuştur. Nasıl Harp Akademisi, Harbiye } \\
\text { ve Mülkiye sıradan eğitim müesseseleri sayılmazsa Galatasaray da sıradan bir lise } \\
\text { sayılamaz."... }\end{array}$ \\
\hline $\begin{array}{l}\text { Atatürk } \\
\text { ve } \\
\text { Galatasaray }\end{array}$ & $\begin{array}{l}\text {..."1 Temmuz 1933, Galatasaray Lisesi'nin yaşadığı en büyük gündür; o gün Gazi Haz- } \\
\text { retleri, müessemizde beş saat bir çeyrek saat kalmışlar, ve birinci devre Tarih-Coğrafya- } \\
\text { Yurtbilgisi mezuniyet imtahanlarına giren talebemizden dokuzunu imtahan etmek lüt- } \\
\text { funda bulunmuşlardır. Galatasaray Lisesi, bundan sonra, o unutulmaz günü her sene } \\
\text { anmak ve tekrar yaşamak için aynı devrenin aynı imtihanlarını daima aynı güne ko- } \\
\text { yacaktı..... }\end{array}$ \\
\hline $\begin{array}{l}\text { İlk } \\
\text { Mabet } \\
\text { Ali Sami } \\
\text { Yen Stadi }\end{array}$ & $\begin{array}{l}\text {...Fenerbahçe Papazın Çayırı'ndaki araziyi mülkiyetine alarak Fenerbahçe Stadı haline } \\
\text { getirirken, Beşiktaş şimdiki Çırağan Sarayı'nın yerinde yer alan Şeref Stadı'na geçti. Aynı } \\
\text { dönemde stat konusunda en büyük problemi Galatasaray yaşadı... } \\
\text {...Bu sorunun aşılması için ilk adımlar 30'lu yılların başında atıldı. Mecidiyeköy'deki } \\
\text { dutluk bir arazinin Galatasaray'a kazandırılması için ilk girişim } 1933 \text { yılında dönemin } \\
\text { başkanı Ali Haydar Barşal tarafından yapılmıştı... }\end{array}$ \\
\hline $\begin{array}{l}\text { Batıya Açılan } \\
\text { Pencere: } \\
\text { Galatasaray } \\
\text { Lisesi }\end{array}$ & $\begin{array}{l}\text { Saray Mektebi Dönemi } \\
\text { Sultanî Dönemi } \\
\text { Lise Dönemi }\end{array}$ \\
\hline
\end{tabular}

Galatsaray SK'nın resmi web sitesi üzerinden yapılan öykü incelemelerinde de diğer iki takımda olduğu gibi Galatasaray SK'nın 'kahraman' arketipiyle konumlandırıldığı gözlemlenmektedir. Kuruluş aşamasında kahraman olarak 'Ali Sami Yen' ismi ön plana çıkmakta, kahramanların yetiştiği yer olarak da tarihi 15. yüzyıla dayanan 'Galatasaray Lisesi' vurgulanmaktadır. Anlatılar içerisinde özellikle "Türk olmayan takımları yenmek" mesajı kuruluştan bugüne dek çok önemli bir amaç olarak konumlandırılmakta, öyküdeki çatışma unsuru da bu mesaj üzerinden oluşturulmaktadır. Çatışma unsurunun yabanci/işgalciler ile Galatasaray arasındaki mücadeleye dayandırıldığı gözlemlenmektedir. Aynı zamanda bu, sadece kuruluşa özgü değil, günümüze kadar devam eden bir mücadele olarak tanımlanmaktadır. Galatasaraylılık ve vatan sevgisi şehitler üzerinden anlatılmakta ve şehitlerin isimleri ve künyeleri de buna dayanak gösterilmektedir.

Galatasaray kulübünün renklerinin öyküsünün de duygusal bir takım unsurlarla aktarıldığı görülmektedir. Sarı ve kırmızının kulübün renkleri olarak seçilmesinde ve kabülünde özellikle, zerafet, parlaklık, ateş gibi metaforlar üzerinden galibiyet mesajının iletildiği görülmektedir.

"Birçok yerleri dolaştıktan sonra, nihayet Bahçekapi'daki Şişman Yanko'nun dükkanma gidilerek orada zarifiki yünlü kumaşa tesadüfettik. Biri, 
vişneye çalan koyuca tatl bir kırmızı, öteki de, içinde turuncudan iz taşıyan tok bir sarı. Tezgahtar, mahirane bir el hareketi ile kumaşlarm dalgalarını birleştirdi. Bir saka kuşunun başı ile kanadının yarattığı renk güzelliğine benzer bir parlaklik hasıl oldu. Ateşin içindeki renk oyunlarını görür gibi olmuştuk. Sarı-Kırmızı alevinin takımımız üstünde parıldamasını tasavvur ediyor ve bizi derhal galibiyetten galibiyete götüreceğini tahayyül ediyorduk. Nitekim de öyle oldu."

Galatasaray SK'nın web sitesi üzerinden iletilen öykülerdeki mesajların etik olma, dayanışma, özveri gibi değerlerle aktarıldığı görülmektedir. Aynı zamanda bağlllık, mücadele ve güçlü duruş tüm öykülerde Galatasaraylılık duruşuyla ilişkilendirilmektedir.

"Ali Sami Yen'in deyimiyle, bu takımlar oluşturan çocukların arasında Alexandre Dumas'nın Üç Silahşörleri'ne benzer bir bağhllık vardır. Kimi zaman hakaretlere uğrayan, kimi zaman dövüşmek zorunda kalan, kimi zaman tutuklanıp, okuldan uzaklaştırılan bu çocuklar, bağlllıktan doğan gücü keşfederler..."

Galatasaray SK'nın resmi web sitesinde aktarılan öykülerde kendisini Atatürk ile özdeşleştirdiği ve Atatürk'ün Galatasaray Lisesi'ni ziyaretlerinin sıklıkla vurgulandığı görülmektedir. Öykü anlatısı içerisinde Atatürk'ün diğer kulüplere bir kez ziyarete gittiği, Galatasaray Lisesini ise 3 defa ziyaret edip, 5 saat kalıp öğrencilere imtihan yaptığı vurgusu dikkat çekicidir.

\section{Trabzonspor' un Resmi Web Sitesinin Öykü Anlatıcılı̆̆ı Açısından Incelenmesi}

Trabzonspor sitesi http://www.trabzonspor.org.tr incelendiğinde öykülerin 'Tarihçe' bölümünde olduğu görülmektedir. 'Tarihçe' başlığı altında '1967'den Önce...', 'Güç-Ocak Rekabeti', 'Trabzonspor'a Doğru...', 'Futbolda Anadolu Devrimi’ ve ‘50. Yılında Karadeniz Fırtınası’ gibi 5 ayrı öyküden oluşmaktadır. Bu öykülerden çalışmaya konu olan Fog ve arkadaşlarının modeli doğrultusunda incelenebilecek öykülerden kesitler Tablo 5 'de yer almaktadır. 
Tablo 5. Trabzonspor'un Resmi Web Sitesinde Yer Alan Öykü Başlıkları ve Kesitleri

..."Osmanlı Devleti'nin Karadeniz'deki en önemli limanlarından biri olan Trabzon, sadece ticari olarak değil; sosyo-kültürel olarak da önemli bir geçiş noktasıydı. Batı' dan gelen her türlü 'yenilik' ilk olarak Trabzon' da hayat bulur; ardından kentin hinterlandında kalan coğrafyaya yayılırdı. Futbol, bunlardan biriydi”....

...'Trabzon, öğreten, aktaran, öncülük eden bir konumdaydı ve iddiası da tarihsel olarak bundan kaynaklanmaktaydı. Bu açıdan düşünüldügünnde, Trabzonspor'un

'1967'den Önce...'

Güç-Ocak Rekabeti

Trabzonspor'a Doğru... 1976 yılında Anadolu'ya şampiyonluğu taşıyan ilk kulüp olmasına kimseler şaşmamalıydı!"...

"Trabzon gençliği, kendi futbolu ve bilgisi ile yetinmemekte, sportif tecrübelerini arttırmak için sürekli arayış içindeydi. Trabzon sınırlarını sürekli zorlayan bir kentti. Henüz 1925 yılında Sovyetler Birliği'nden kente davet edilen spor kafilesi ile ilk yurtdışı temas da gerçekleştirilmişti. Bu da bir ilkti. İlerleyen yıllarda ise her fırsatta kente İstanbul, İzmir, Ankara, hatta İran ve hatta Avusturya' dan takımlar davet edilecek; Trabzonlular meşin yuvarlakla tanıştıkları ilk günden bu yana, futbola 'yerel'in ötesinde bir anlam atfedecekti."...

"İdmanocağı, İdmangücü, Necmiati, Birlikspor, Karadenizgücü, Doğanspor, Yolspor, Martıspor, Erdoğdu Gençlik ve Trabzon Lisesi başta olmak üzere Trabzon amatör liginden pek çok kulüp gelip geçti. Bu kulüpler aynı zamanda "içtimai" birer dernek olarak faaliyet gösteriyor; tiyatro, piyes, balo ve musiki konseri gibi düzenledikleri farklı etkinliklerle kentin kültürel yaşamını renklendiriyordu." ...

...“Ocak-Güç derbisi şehirde adeta bir karnaval havası yaratırdı. Rengârenk flama ve bayraklarla donatılan kentte binlerce futbolsever maç saatinin gelmesini beklerken, tutuşulan bahisler ve iddialarla rekabetin dozu arttırılırdı. Rakip taraftarlar karşı tarafın renklerine boyadıkları bir tabutu veya eşeği kentin meydanlarında, sokak aralarında gezdirirlerdi. Maç saati geldiğinde Şehir Stadı́ndaki yerlerini alan futbolseverler "şa-şa-şa" dan pek de öteye gidemeyen tezahürat, ama bitmeyen coşkularıyla takımlarına destek olurlardı" ....

..."1960'ların ilk yarısında Futbol Federasyonu Başkanı Orhan Şeref Apak'ın öncülüğünde profesyonel ikinci ve üçüncü ligler kurulmuştu. Tüm yurtta bu liglerde mücadele edecek profesyonel şehir takımlarının kurulması öngörülüyordu. Kentin maddi, manevi ve sportif tüm imkânlarının profesyonel bir spor kulübüne seferber edilebilmesi için o kentteki amatör kulüplerin birleşmesi gerekiyordu. Trabzon elbette ki bu seferberliğin dışında kalamazdı. Ancak İdmanocağı-İdmangücü rekabeti Trabzon futboluna öylesine hakimdi ki bu iki kulübün bir çatı altında toplanması neredeyse imkansızdı."...

...“Nihayet 2 Ağustos 1967 günü, geceli gündüzlü yapılan toplantılardan müsbet bir netice çıkacak ve her iki kulüp birleşmeyi kabul edecekti. Bordo-Mavi renkler altında, İdmanocağı, İdmangücü, Karadenizgücü ve Martıspor'un birleşmesi ile kurulan Trabzonspor Kulübü, 1967-68 sezonu itibarıla İkinci Lig'e "merhaba" dedi."...

"Trabzonspor uzun uğraşlar sonucu kurulduktan sonra İkinci Lig'deki mücadelesine daha ilk sezondan itibaren Birinci Lig'e çıkma hedefi ile başladı.

Futbolda

Anadolu 'Trabzon futbolu'nun layık olduğu yer kesinlikle İkinci Lig olarak görülmüyor;

Devrimi Trabzonluların Bordo-Mavili kulüpten beklentisi, gücünü övgülerle anılan bir maziden alıyordu. "Yıllarca memleket sporuna önderlik etmiş" bir kent, nasıl İkinci Lig'de kalabilirdi? ... 


\begin{tabular}{ll}
\hline & $\ldots$ “Trabzonspor, 50 yıllık mazisi boyunca kimi zaman dramatik kaybedişlerin \\
& kimi zaman sarsıcı başarı ve unutulmaz galibiyetlerin takımı oldu. Ama her \\
& dönem ve koşulda bir spor kulübünden çok daha fazla şeyi temsil ediyordu. \\
& "Kemençeden tuluma, horondan kolbastıya, hamsisi, şivesi ve hirçın doğasıyla \\
50. Yılında & Karadeniz'e dair pek çok folklorik ve kültürel sembolün taşıyıcısı ve ulusal dü- \\
Karadeniz & $\begin{array}{l}\text { zeyde sergilendiği zemindi Trabzonspor. Bu, şüphesiz ki onu diğer kulüpler- } \\
\text { Firtınası }\end{array}$ \\
& den ayıran en belirleyici özelliklerden biriydi. Diğeri mi? Umudun, inanç, mü- \\
& cadele ve sevdanın takımı olması"... \\
\hline
\end{tabular}

Trabzonspor'un resmi web sitesi üzerinden incelenen bu öykülerde zayıf durumdan güçlü bir duruma dönüşümün anlatıldığı bir olay örgüsü ön plana çımaktadır. Kahraman olarak gösterilen Trabzonspor aynı zamanda asi arketipiyle de ilişkilendirilmekte, öykülerde kendisine verilen rolü kabul etmeyen bir karakterle konumlandırılmaktadır. Trabzon şehrinin ve kültürünün sıklıkla öykülerin içerisinde yer alması taraftara kendisini bir şehre ait hissettirme mesajıyla dikkat çekmektedir.

Öykülerde verilen mesajlarda özellikle 'Karadeniz Fırtınası' betimlemesi de bunun bir göstergesi olarak tanımlanabilir. Aynı zamanda çalışmaya konu olan 3 İstanbul kulübünden farklı olarak, Trabzonspor'un kendisini Anadolu kulüplerinin temsilcisi rolüyle ilişkilendirdiği de görülmektedir. Bu temsilci rolünün pekiştirilmesinde öykülerde ve anlatı örgüsünde özellikle kemençe, tulum, horon, kolbastı, hamsi, Trabzon şivesi, hırçın doğa gibi kültürel bir takım sembollerin vurgulandığı görülmektedir. Bunların yanı sıra kulübün değer yaratması açısından iletilen mesajlardaki vurgular incelendiğinde, 'umut, inanç, mücadele ve sevdanın takımı' olma gibi özellikler ön plana çıkmaktadır.

Bordo mavi renklerle kendisini ifade eden kulüp öykülerinde ilettiği mesajlarda spor kulübü olmaktan daha fazla şeyi temsil etmek, şampiyonluğu ilk defa İstanbul dışına taşıyarak Türk futbolunda yerleşik her ne varsa altüst etmek ve bir devrime imza atmış olmakla kendi kahramanlıklarını "Kupa Beyi" deyişiyle öyküleştirmekte, buna dayanarak da saygınlık elde etmek adına devam eden bir mücadeleyi olay örgüsü olarak anlatıya dönüştürmektedir.

\section{Sonuç ve Değerlendirme}

Futbolun 1980'li yıllarda ön plana çımasında bu dönem içerisinde dünyada yaşanan ekonomik gelişmeler, ideolojik yapı ve neo liberal dalganın futbolun 
endüstriyelleşme sürecinde etkili olduğu kabul görmektedir. Küreselleşme her türlü toplumsal dinamiği derinden etkilediği gibi spor alanında da ortak değerlerin, kodların paylaşımını beraberinde getirmektedir. Hali hazırda kurallar doğrultusunda oynanan futbol tüm toplumların futbola yüklediği anlamlar açısından da benzer düşünce ve davranış kalıplarının ortaya çıktığı bir alan olarak tanımlanabilir. Buradan hareketle birbirine benzeyen statların inşa edilmesi, yıldız futbolcuların ortaya çıkışı, her sezon yenilenen formalar, sponsorluk anlaşmaları, kulüplerin birer marka ya da şirketmiş gibi hareket etmesi gibi birçok ortak unsur küreselleşme olgusunun futbola etkisini gözler önüne sermektedir.

Endüstriyel futbol olarak ele alınan süreç tam da bu noktada futbolu tekrar başka bir bakış açısıyla değerlendirmemizi sağlamaktadır. Bilinir ya da tanınır olmak bir kulüp ya da futbolcunun geleceği açısında oldukça önemli bir amaç olarak algılanmaktadır. Yeşil sahada oynanan oyunun ötesinde kulüplerin tıpkı bir marka ya da şirket gibi davranmaları gerekliliği buradan doğar. Bahsi geçen profesyonelleşme futbol kulüplerini değişime ayak uydurmaya zorlamaktadır. Şirketlerin marka değeri yaratmada kullandıkları yol ve yöntemler futbol kulüpleri açısından da önemsenmesi gereken birer strateji haline dönüşmektedir.

Bu süreç, tıpkı kurum ve markalarda olduğu gibi futbol kulüplerinin de pazar ve rekabet gibi unsurları gündemine taşıması ihtiyacına işaret etmektedir. Bu nedenle futbol kulüpleri gerek taraftarlarında gerekse ülke ya da dünya kamuoyunda iyi bir izlenim yaratabilmek, marka değeri oluşturabilmek, saygın bir imaj dizayn edebilmek adına öykü anlatıclığının gücünden faydalanmaktadır. Hedef kitlelerinde güçlü bir imaj yaratmak isteyen futbol kulüpleri kendi öykülerini taraftarlarına aktarmakta ve marka değeri yaratma konusunda öykü anlatıcılığını bir araç olarak konumlandırmaktadır.

Çalışma kapsamında Türkiye'nin dört büyük spor kulübü olarak kabul edilen Beşiktaş JK, Fenerbahçe SK, Galatasaray SK ve Trabzonspor'un resmi web sayfalarının Türkçe versiyonu temel alınmıştır. 01-09 Nisan 2019 tarih aralığında incelenen bu sayfalarda çeşitli sekmeler altında öykü unsurlarının izi sürülmüştür. Bunun sonucunda kulüplerin resmi internet sayfalarında çeşitli öyküler olduğu görülmüş, öyküler belli kategoriler üzerinden incelenmiştir. Kategorilerin oluşturulmasında Fog ve arkadaşlarının çekirdek öykü modeli kullanılmıştır. Buna göre öykünün temelini oluşturan dört temel un- 
sur bulunmaktadır. Bu dört unsur "mesaj, çatışma, karakterler ve olay örgüsü" olarak tanımlanmaktadır. Bu doğrultuda şu çıkarımlara varmak mümkündür;

Dört spor kulübünün de resmi internet sayfalarında öykü anlatıclığı unsurlarına yer verildiği görülmektedir. Öyküler dört temel unsur (mesaj, çatışma, karakterler ve olay örgüsü) üzerinden incelendiğinde mesajlarda kulüplerin kendilerini kuruluş döneminden başlayarak kahraman arketipi özelliklerine karşılık gelecek şekilde konumlandırması göze çarpmaktadır. Kahraman arketipi özelliklerine bakıldığında cesur, sağlam duruş gösteren ve kendine güvenen karakter özelliklerinin olduğu görülmektedir. Kahraman arketipi aynı zamanda daha iyi bir dünya için mücadele etmekte, içinde bulunduğu kötü bir durumu iyileşirmek için savaşmaktadır. Kahraman arketipinin mücadelesi korku, zayıflık ve kötülük üzerine kuruludur. Yapılan öykü incelemelerinde de dört takımın da öykülerindeki örüntü ve karakterler tam da bunun tezahürüdür. Özellikle Beşiktaş JK, Galatasaray SK ve Fenerbahçe SK'nın kuruluş dönemlerine ve ilk yıllarına denk gelen 1. Dünya Savaşı ve Kurtuluş Savaşı gibi milli mücadeleler ile kendi öykülerini harmanlaması tüm taraftarlara hitap edebilecek vatanseverlik, millet, fedakarlık gibi unsurların ön planda olduğu anlatıları ön plana almaktadır. Bu öykülerde kurucu kahraman kulübü için kendini feda etmekte ya da oyuncular düşman takımları yenip galibiyete ulaşmaktadır. Anlatılarda yer alan bu mücadeleler ve sonucunda elde edilen galibiyetler savaş yıllarında halka ilham vermekte, halkın ayakta kalmasında ve güçlenmesinde de önemli rol oynamaktadır. Tüm bu unsurlar çalışmaya konu olan kulüplerin ortak tarihi bir bağ oluşturma ve kollektif bir tarih bilinci üzerinden taraftarlarına seslenme biçimidir. Denilebilir ki bu noktada taraftarlarıyla oluşturulacak duygusal tabanlı iletişim öykü anlatıcılığı unsurlarından faydalanılarak sağlanmakta, kulüple taraftar arasında sadakatin güçlü tutulmasına dayanak oluşturmaktadır.

Trabzonspor kulübünün kuruluşunun 1960'lı yılların sonlarına dayanması bu tür milli mücadele, savaş ve milliyetçilik gibi özelliklerin arka planda olduğu bir olay örgüsünü karşımıza çıkarmaktadır. Trabzonspor'un aktarılan öykülerde başka bir çatışmanın kahramanı olduğu görülmektedir. Öykülerinde güçlü, dev İstanbul kulüplerine karşı mütevazı bir takım olarak bölgenin ve tüm Anadolu'nun temsilcisi olarak kendini konumlandırmaktadır. Buna dayanan örüntülerde Trabzonspor asi, devrimci yanı ile büyük İstanbul kulüplerine meydan okuyan bir kahraman olarak gösterilmektedir. 
Dört takımın resmi web sitelerinde öyküler aktarılırken, kulüplerin Atatürk ile ilişkilendirilmesi dikkat çekicidir. Atatürk'ün tuttuğu takım olmak ve taraftarları buna inandırmak için öykü anlatıcılığından faydalanılmakta, bunun üzerinden kulübe saygınlık ve itibar oluşturulmaktadır.

Dört kulübün resmi web sitelerindeki öykülerin metin olarak aktarıldığ1 ancak bunun yanı sıra öykülerdeki olaylar, karakterler ve mekanlara ilişkin bazı görsellerin de kullanıldığını söylemek mümkündür. Burada değinilmesi gereken çok önemli bir nokta da öykülerin tek yönlü bir biçimde, geleneksel anlatılarla aktarılmasıdır. Bu bağlamda kullanıcıların ürettiği ya da paylaştığ öykülere yer verilmediğini söylemek mümkündür. Öyküler her ne kadar dijital platformlar üzerinden iletiliyor olsa da, öykülerin aktarılmasında 'dijital öykü anlatıcılığı' unsurlarına yer verilmediği gözlenmiştir. Bunun yanında Türkiye'de farklı branşlarda pek çok spor kulübünün öykülerini incelemek, özellikle de taraftar gözü ile bu öykülere bakmak sonraki çalışmalarda spor iletişimi literatürü için de fayda sağlayacaktır. 


\title{
EXTENDED ABSTRACT
}

\section{Storytelling and Football: An Investigation On The Stories of 'Four Great Team's Web Sites}

\author{
Özge Uğurlu Akbaş - Sadık Çalışkan \\ Üsküdar University, İnönü University
}

Studies in the field of psychology and neuroscience show that the stories affect consumers' perception of the brand and its commitment to the brand. Brands are considered as a sum of the anticipations, memories, and stories about a certain company, product or service in the minds of consumers. In this sense, stories are considered as one of the most important means of establishing an emotional connection between brands and consumers. Sports has been an important part of the culture since ancient times. It is still a vital part of daily communication. More than 4 billion people are engaged in sports as either athletes or spectators. Football is the most popular kind of sports which people like to play, watch or talk. It has become a giant industry in which teams become brands that fans van identify themselves with. They develop emotional ties with the sport teams through stories. Through these stories people from different backgrounds, families, subcultures or ethnicities can unite and around the colors and the flag of the team. Sports clubs also use story and storytelling elements when communicating with their supporters. Beşiktaş JK, Fenerbahçe SK, Galatasaray SK and Trabzonspor are known as "the four great teams" in Turkey because of the multiple championships they won in their history. They are also the most popular sport teams in Turkey. According to the KPMG European Elite Report 2018 the three of the four teams, Galatasaray, SK, Beşiktaş JK and Fenerbahçe SK are among the 100 valuable football clubs of Europe. In this study, Turkey's four major sports clubs, Beşiktaş JK, Fenerbahçe SK, Galatasaray SK and Trabzonspor's official web pages were viewed by using the core story model of Fog et al. Accordingly, there are four basic elements that form the basis of the story. These four elements are defined as "messages, conflicts, characters and event patterns". According to the authors messages are the core parts or the lessons of the story. Conflict which is to recreate 
harmony disturbed is the driving force of the story. In order to create harmony a hero has to struggle with other characters, nature or himself. Another element of the story is the characters. Although the turning point of the story is conflict, without interacting characters, it is impossible to create conflict or tension. The last element of the story is the plot, or the flow and progression. In order to take and maintain reader's attention, the sequence of events is to have a precise structure predicting what is coming, so to implement the theme and tone of the story. The questions we tried to answer are; how storytelling is used in the webpages of four great teams, what kinds of stories are used and how storytelling is used while communicating with supporters.

In this study, qualitative content analysis is used as data collection method. This method is used to determine the presence of certain words, concepts, themes, expressions, sentences in texts and to measure this entity objectively. Content analysis is a systematic analysis of social scientists to give meaning to the information obtained from archives, documents, newspapers, various visual documents such as cinema, series, and various mass media. In a more concrete way, examining court decisions on specific issues, reviewing newspaper news, examining the history archives between various dates, examining how television images are reflected, reviewing novels, etc. Such topics can be cited as an example. Content analysis techniques have increasingly been used to analyze content on Internet pages in recent years. The research universe is football clubs, which are a very important area of sports communication. The study was was limited to the clubs called 'Four great teams' in Turkish football.

It is seen that the storytelling elements are included in the official websites of all four sports clubs. When the stories are analyzed on four basic elements (message, conflict, characters and plot), it is striking that the clubs position themselves in correspondence with the archetypal features starting from the establishment period. When the archetypal features of the hero are analyzed, it is seen that there are bold, strong posture and confident character traits. The hero archetype also fights for a better world and fights to heal a bad situation. The struggle of the hero archetype is based on fear, weakness, and evil. The patterns and characters in the stories of all four teams are exactly the manifestation of this. Particularly, Beşiktaş JK, Galatasaray SK and Fenerbahçe SK combine their own stories with the national struggles 
such as the First World War and the War of Independence, which coincided with the foundation periods and first years, and elements such as patriotism, nation, and altruism are at the forefront. brings the narratives to the fore. In these stories, the founder hero sacrifices himself for the club or the players defeat the enemy teams and reach the victory. These struggles in the narratives and the victories achieved as a result inspire the public during the war years and also play an important role in the survival and empowerment of the public. All these elements are the way the clubs subject to the study form a common historical bond and address their fans through a collective history consciousness. It can be said that at this point, emotional based communication with the supporters of the story is provided by making use of the storytelling elements, and it provides a basis for keeping the loyalty strong between the club and the fans.

\section{Kaynakça / References}

Alexander, B. (2011). The new digital storytelling: Creating narratives with new media. Santa Barbara, CA: ABC-CLIO.

Baker, B. ve Boyle, C., (2009). The timeless power of storytelling. Journal of Sponsorship, 3(1), 79-87.

Barthes, R. (1975). An introduction to the structural analysis of narrative. New literary history, 6(2), 237-272.

Bausch, W. J. (2004). In the beginning, there were stories: Thoughts about the oral tradition of the Bible. Mystic, CT: Twenty-Third Publications.

Benjamin, B. (2006). The case study: Storytelling in the industrial age and beyond. On the Horizon, 14(4), 159-164.

Beşiktaş (t.y) Tarihçe. https://bjk.com.tr/tr adresinden erişilmiştir.

Boyd, B. (2009). On the origin of stories. Cambridge, MA: Harvard University Press.

Campbell, J., ve Moyers, B. (2011). The power of myth. New York, NY: Anchor Books.

Clubs'Valuation, F. (2018). The European Elite 2018.

Czarniawska, B. (2004). Narratives in social science research. London: Sage.

Denning, S. (2001). The springboard: How storytelling ignites action in knowledge-era organizations. Boston, MA: Routledge.

Denning, S. (2016). What is a story? What is narrative meaning http://stevedenning.com/Business-Narrative/definitions-of-story-and-narrative.aspx adresinden erişilmiştir. 
Direction, S. (2008) Tall tales?: Storytelling for marketers, change managers and operational researchers. Strategic Direction, 24(7), 27-29.

Eldrbarry, (2016). What Storytelling is: An attempt at defining the art form. http://www.eldrbarry.net/roos/st defn.htm adresinden erişilmiştir.

Fenerbahçe (t.y) Tarihçe. https://www.fenerbahce.org/ adresinden erişilmiştir.

Fog, K., Budtz, C., Munch, P., ve Blanchette, S. (2010). Storytelling: Branding in practice. Heidelberg: Springer.

Galatasaray (t.y) Tarihçe. https://www.galatasaray.org/ adresinden erişilmiştir.

Gazzaniga, M. S. (2008). Human: The science behind what makes us unique. New York, NY: Harper Collins.

Gladden, J.M. and Funk, D.C. (2002) Developing an understanding of brand associations in team sport: Empirical evidences from consumers of professionalsport. Journal of Sport Management 16(1), 54-81.

Gottschall, J. (2012). The storytelling animal: How stories make us human. Houghton: Mifflin Harcourt.

Green, M. C., ve Brock, T. C. (2000). The role of transportation in the persuasiveness of public narratives. Journal of personality and social psychology, 79(5), 701.

Harari, Y. N. (2014). Sapiens: A brief history of humankind. London: Harvill Secker.

Haven, K. (2014). Story Smart: Using the science of story to persuade, influence, inspire, and teach. Santa Barbara, CA: ABC-CLIO.

Haven, K. F. (2007). Story proof: The science behind the startling power of story. Westport, CT: Greenwood Publishing Group.

Herring, S. C. (2009). Web content analysis: Expanding the paradigm. International handbook of Internet research içinde (s.233-249). Dordrecht: Springer.

Herskovitz, S. ve Crystal, M. (2010). The essential brand persona: story-telling and branding. Journal of Business Strategy, 31(3), 21-28.

History, C. (2016). The day in history. http://www.history.com/this-day-in-history/welles-scares-nation adresinden erişilmiştir.

Holt, D.B. (2004). How brand become icons: The principles of cultural branding. Boston MA: Harvard Business School Press.

Ibrahim A, Stuart R. ve Daniel H., (2012) Examining the relationship between brand emotion and brand extension among supporters of professional football clubs. European Journal of Marketing, 46(9), 1233-1251.

Jensen, K.B. (2011). New media, old methods- internet methodologies and the online/offline divide. (M. Consalvo ve C. Ess, eds). The Handbook Of Internet Studies içinde (s.43-58), Wiley- Blackwell, Malde, MA. 
Kaufman, J. E., Herzog, A. F. (2006). The collected poems of Muriel Rukeyser. Pittsburgh. PA: University of Pittsburgh Press.

Lockett, M. (2007). Mike Lockett. http://www.mikelockett.com/home.php adresinden erişilmiştir.

Lusensky, J. (2015). Brandpsycho four essays on de branding. Zürich: The Zurich Lab. Mendoza,M.(2015). The evolution of storytelling. http://webcache.googleusercontent.com/search?q=cache:Gza9RuaoIRoJ:https://reporter.rit.edu:8443/tech/evolution-storytelling\&hl=tr\&gl=tr\&strip $=1 \& v w s r c=0$ adresinden erişilmiştir

National Storytelling Association. (1999). National storytelling network. https://storynet.org/adresinden erişilmiştir.

Parker, K., ve Stuart, T. (1997). The west ham syndrome. Market research society. Journal , 39(3), 1-8.

Pink, D. H. (2006). A whole new mind: Why right-brainers will rule the future. New York, NY: Penguin.

Sachs, J. (2012). Winning the story wars: Why those who tell--and live--the best stories will rule the future. Boston MA: Harvard Business Press.

Shankar, A., Elliot, R. ve Goulding, C. (2001). Understanding consumption: Contributions from a narrative perspective. Journal of Marketing Management, $17(3-4), 429-453$.

Simmons, A. (2006). The story factor: Inspiration, influence, and persuasion through the art of storytelling. Cambridge, MA: Basic Books.

Sinclair, J. (2005). The impact of stories. Leading Issues in Knowledge Management Research, 3(1), 53-64.

Strangelove. M. (2010). Watching YouTube: Extraordinary videos by ordinary people. University of Toronto Press.

Trabzonspor (t.y) Tarihçe. https://www.trabzonspor.org.tr/tr adresinden erişilmiştir.

\section{Kaynakça Bilgisi / Citation Information}

Uğurlu Akbaş, Ö. ve Çalışkan, S. (2020). Öykü anlatıc1lı̆̆1 ve futbol:'dört büyükler'in internet sitelerinde aktarılan öyküler üzerine bir inceleme. OPUS-Uluslararası Toplum Araştırmaları Dergisi, 15(22), 1200-1233. DOI: 10.26466/opus.592530 